\title{
HACIA UN ANÁLISIS GENERAL A LARGO PLAZO DEL DESARROLLO ECONÓMICO DE MÉXICO *
}

\author{
LEOPOLDO SOLÍS M. \\ El Colegio de México
}

Quienes aNALIZAN EL desarrollo económico de México, suelen, por lo general, concretarse al periodo iniciado en 1940. Esto se debe en parte a la limitada información de que se dispone. Sin embargo, los acontecimientos del México actual y del desarrollo económico del país se remontan a finales del siglo pasado. A principios del Porfiriato (1876) se inició el proceso continuado de formación de capital, fundamentalmente con la construcción de ferrocarriles. Desde entonces emprendió México la creación de su infraestructura moderna. Este proceso de desarrollo económico se interrumpió poco antes de la Revolución y una parte del acervo de capital fue destruida. La fuerza de trabajo descendió como resultado de las luchas armadas y de enfermedades, epidemias y emigración. El México postrrevolucionario, cuando apenas empezaba a recuperarse de los efectos de la lucha armada, se vio afectado por la gran depresión de 1929-1933, si bien en forma no muy severa. Durante los años treinta ocurrieron importantes cambios en la estructura económica mexicana. Estudiar la economía a partir de 1940 es en cierto modo observar el resultado de un proceso sin saber cómo comenzó y se desenvolvió. En consecuencia, conviene esbozar al menos los hechos más importantes del desarrollo económico previo a 1940.

I. Principios del proceso de Formación de Capital y del Mercado DE TRABAJO

Poco antes de iniciarse la guerra de Independencia, según José María Quiroz, secretario del Real Consulado de Veracruz, el valor de la produción agrícola, minera e industrial del Virreinato de la Nueva España ascendía a 190 millones de pesos. De tal cifra, el $56 \%$ correspondía a las actividades agropecuarias, el $15 \%$ a las mineras y el $29 \%$ a las industriales; desde principios del siglo pasado las actividades industriales aportaban una cantidad nada despreciable del valor de la pro-

* Este trabajo fue preparado en 1965 para contribuir a diseñar el programa de investigación del Centro de Estudios Económicos y Demográficos de EI Colegio de México. Su propósito fundamental es establecer hipótesis y asignar prioridades a proyectos individuales de investigación. Como el autor trata de plantear hipótesis y no de probarlas, ruega se le conceda licencia y se le exima de las exigencias metodológicas y de información estadística que circunscriben, por lo general, este tipo de trabajos. 
ducción nacional. ${ }^{1}$ La inestabilidad política, que matizó la vida mexicana durante la guerra de Independencia y los primeros decenios del México independiente, no impidió que a mediados del siglo se establecieran fábricas que utilizaban ciertos adelantos tecnológicos de la revolución industrial, tales como: motores de vapor, husos, telares mecánicos, etc. Se instalaron fábricas, aunque de pequeño tamaño, de telas de algodón y lana, papel, vidrio y otras. Las dificultades a que se enfrentaban los productores para operar a niveles que rindieran economías de escala eran, sin embargo, casi insuperables, debido a deficiencias de localización y a la falta de integración de los mercados locales en un mercado nacional. Esto era resultado de las alcabalas, de las deficiencias del transporte $y$, en general, de la autarquía económica.

Los pequeños establecimientos fabriles y los talleres artesanales fueron el embrión de la industrialización del país, proceso que habría de afirmarse durante la República Restaurada y especialmente en el Porfiriato. En cambio, las artesanías indígenas estaban vinculadas a una economía de autoconsumo que producía poco para el mercado, en tanto que las de origen hispánico se localizaban en las ciudades. Estas últimas sustentaron el comienzo del desarrollo mercantil y aportaron la reserva de mano de obra que alimentó el posterior crecimiento industrial.

La restauración de la República afirmó la existencia del país en lo político. Sin embargo, en lo económico se estaba aún lejos de haber alcanzado la integración nacional. Un primer paso fue la desamortización de bienes de la Iglesia y de las comunidades indígenas, que provocó un cambio sustancial en las relaciones de producción.² Las tierras de cultivo propiedad del clero y de las comunidades indígenas que se especializaban en la producción de bienes para el autoconsumo fueron sustituidas por la agricultura latifundista, la cual comenzó a orientarse hacia el mercado, impelida por las necesidades de consumo de los duenos, inclinados a adquirir bienes importados. De esta manera, los antiguos miembros de las comunidades pasaron a trabajar como peones de las haciendas, a endeudarse en las tiendas de raya y a perder el derecho de contratarse libremente en el mercado. Este proceso que desquició las comunidades y las entregó a los hacendados puede compararse en muchos de sus efectos económicos con la conocida etapa de los enclosures que precedió a la revolución industrial inglesa. En las ciudades, donde la riqueza consistía principalmente en edificios, tierras y capital comercial —en forma de inventarios-, la desamortización creó posibilidades de ganancia hasta entonces inexistentes; en la compraventa de los bienes urbanos liberados se acumularon capitales que pusieron a sus poseedores en condiciones de emprender o financiar empresas mayores. Una de éstas fue producir bienes para el mercado

1 Fernando Rosenzweig, "La economía novohispana a principios del siglo XIX", Ciencias Políticas y Sociales, Año IX, Núm. XXXIII, pp. 455-494, UNAM, julio-septiembre de 1963.

2 Lucas Alamán estimó que, a principios del siglo XIX, las propiedades urbanas y rurales de la Iglesia y las propiedades que garantizaban sus créditos e intereses superaban la mitad de los bienes raíces del país. Historia de México, México, 1883, tomo I, capítulo 2. 
interno usando nuevas técnicas. Las primeras instalaciones fabriles destinadas a satisfacer la demanda interna fueron obra de residentes, muchos de ellos extranjeros ocupados en actividades comerciales.

La movilidad de los factores productivos se cita con frecuencia como condición necesaria del proceso de desarrollo económico. Si algo puede inferirse de este estudio es que cada nueva oportunidad de asignar factores a usos distintos, más eficientes, recibe respuesta en forma de mayor dinámica productiva. La ley de nacionalización de los bienes eclesiásticos, promulgada por el gobierno de Juárez en el año 1859, que permitió que con la propiedad urbana y rural se emprendieran nuevas actividades, fue, en efecto, un paso hacia la economía capitalista basada en transacciones de mercado.

El desarrollo iniciado durante el Porfiriato también fue propiciado por el sector externo. Dos factores actuaron en este sentido. Por un lado, las inversiones extranjeras directas, que encontraron campo de acción propicio en la economía mexicana y fueron cuantiosas en los ferrocarriles, el comercio, la minería y la industria; por otro, la demanda externa de mercancías de exportación aumentó y los ingresos por concepto de exportación de bienes ascendieron más o menos en forma continua. El aumento del ingreso, la orientación de la agricultura hacia el mercado, la formación de un proletariado agrícola e industrial y la más estrecha vinculación interna y con el exterior, debido a mejores comunicaciones, crearon mercado interno y facilitaron la obtención del externo: Los factores productivos podían ahora ser utilizados en aprovechar las oportunidades de ganancia que se presentaban. Junto con estos fenómenos coadyuvaron decisiones de política económica en apoyo de esas tendencias, como fueron los subsidios a la construcción de ferrocarriles, la protección arancelaria a la naciente industria y la depreciación de la moneda que, ligada a la plata, se devaluó hasta principios del siglo $\mathrm{xx}$.

Los sectores de la producción. De 1877 a 1907, la producción agrícola aumentó a una tasa anual inferior al $1 \% .^{3}$ La de alimentos y bebidas, productos de consumo interno, decreció, en tanto que la de materias primas subió a una tasa anual superior al conjunto, $2.6 \%$. (Véase el cuadro 1.) Más importante aún, la producción para la exportación creció a una tasa media anual de $6.3 \%$ entre 1877 y 1910 ; la orientación de la producción agrícola hacia la exportación acostumbró a los empresarios agrícolas a conocer los indicadores del comportamiento del mercado, observar los precios, examinar los desplazamientos de la demanda y defenderse de los especuladores. (Véase el cuadro 2.) Sin embargo, las características de la agricultura latifundista impidieron que se generalizaran las mejoras al equipo productivo, la introducción de obras de riego y en general el uso de insumos más productivos; vino un estancamiento, y en algunos casos un descenso, de la producción agrícola para consumo interno. A pesar de que este sector fue un usuario importante del crédito bancario, no parece haber seguido

${ }^{3}$ Las cifras de esta parte, salvo indicación, se tomaron de Daniel Cosío Villegas, Historia moderna de México, tomo VII : El Porfiriato. Vida económica, México, 1965; y Estadisticas económicas del Porfiriato. Fuerza de trabajo y actividad económica por sectores, El Colegio de México, 1964. 
un proceso amplio de capitalización, ya que se hipotecaban las propiedades para solventar los gastos corrientes de los propietarios, quienes en esta forma ayudaban a congelar la cartera de los bancos hipotecarios y comerciales. Este fenómeno era resultado del control del poder político por la aristocracia latifundista.

\section{Cuadro 1}

MÉxico: Volumen dE LA PRoducción, 1877 a 1907

(Tasas medias anuales de incremento)

\begin{tabular}{lcccc}
\hline & \multicolumn{4}{c}{ Agricultura } \\
\cline { 2 - 4 } & Total & $\begin{array}{c}\text { Materias } \\
\text { primas }\end{array}$ & $\begin{array}{c}\text { Alimentos } \\
\text { y bebidas }\end{array}$ & $\begin{array}{c}\text { Bienes de } \\
\text { exportación }\end{array}$ \\
\hline $1877-1892$ & -1.48 & 0.19 & -2.32 & 8.07 \\
$1892-1907$ & 2.81 & 4.95 & 2.37 & 4.87 \\
$1877-1907$ & 0.65 & 2.55 & -1.39 & 6.45 \\
\hline \multicolumn{5}{c}{ Industria } \\
\cline { 2 - 4 } & Totat & Manufac- & Comercio a \\
& turera & Metalúrgica & \\
\hline $1877-1892$ & 11.98 & 13.15 & 9.49 \\
$1892-1907$ & 8.12 & 9.41 & 6.55 & \\
$1877-1907$ & 10.65 & 12.12 & 9.17 & 12.38 \\
\hline
\end{tabular}

a Ventas.

Fuente: Estadísticas económicas del Porfiriato. Fuerza de trabajo y actividad económica por sectores, El Colegio de México, 1964; y datos tomados de Daniel Cosío Villegas, Historia moderna de México, tomo VII: El Porfiriato. Vida económica (Luis Cossío Silva, "La agricultura"; Fernando Rosenzweig, "La industria")

La orientación hacia el mercado externo fue también característica de la ganadería. La producción ganadera se concentraba en las haciendas de mayor tamaño, las cuales se dedicaban preferentemente a la cría de ganado bovino, en producción extensiva y con poco uso de mano de obra. Es interesante observar que el rendimiento de la carne en canal bajó de los primeros a los últimos años del Porfiriato. Este hecho, que nos ilustra el comportamiento del empresario agrícola de esa época, muestra la incapacidad del latifundismo para realizar cambios técnicos o mejoras de la productividad, que hubieran podido alimentar a una población creciente y allegarse las divisas necesarias para importar el equipo que exigía la industrialización.

Más claros resultan estos hechos en cuanto se refieren a la producción agrícola para el consumo interno. La producción de maíz descendió en términos absolutos y relativos. El maíz bajó del $52 \%$ del total en 1877 al $33 \%$ en 1907. En cambio, los productos de exportación ascendieron del 4 al $20 \%$ en el mismo período. La producción agrícola para la exportación, y la de materias primas para la industria, superó en términos relativos a la agricultura de consumo interno, así que el deterioro de esta última vino aparejado con la desamortización de las 
tierras de la Iglesia y de las comunidades y puede haber sido consecuencia de la nueva orientación que daban los propietarios a la tierra. Los aumentos de la producción debíanse al uso más amplio de los mismos insumos y no a cambios de su composición. En este sentido el incremento de la producción se debió principalmente a la ampliación del área cultivada y no al aumento de los rendimientos por hectárea.

\section{Cuadro 2}

MÉXICO: EXPORTACIONES A PRECTOS CORRIENTES, 1877-78 A 1960

(Millones de pesos)

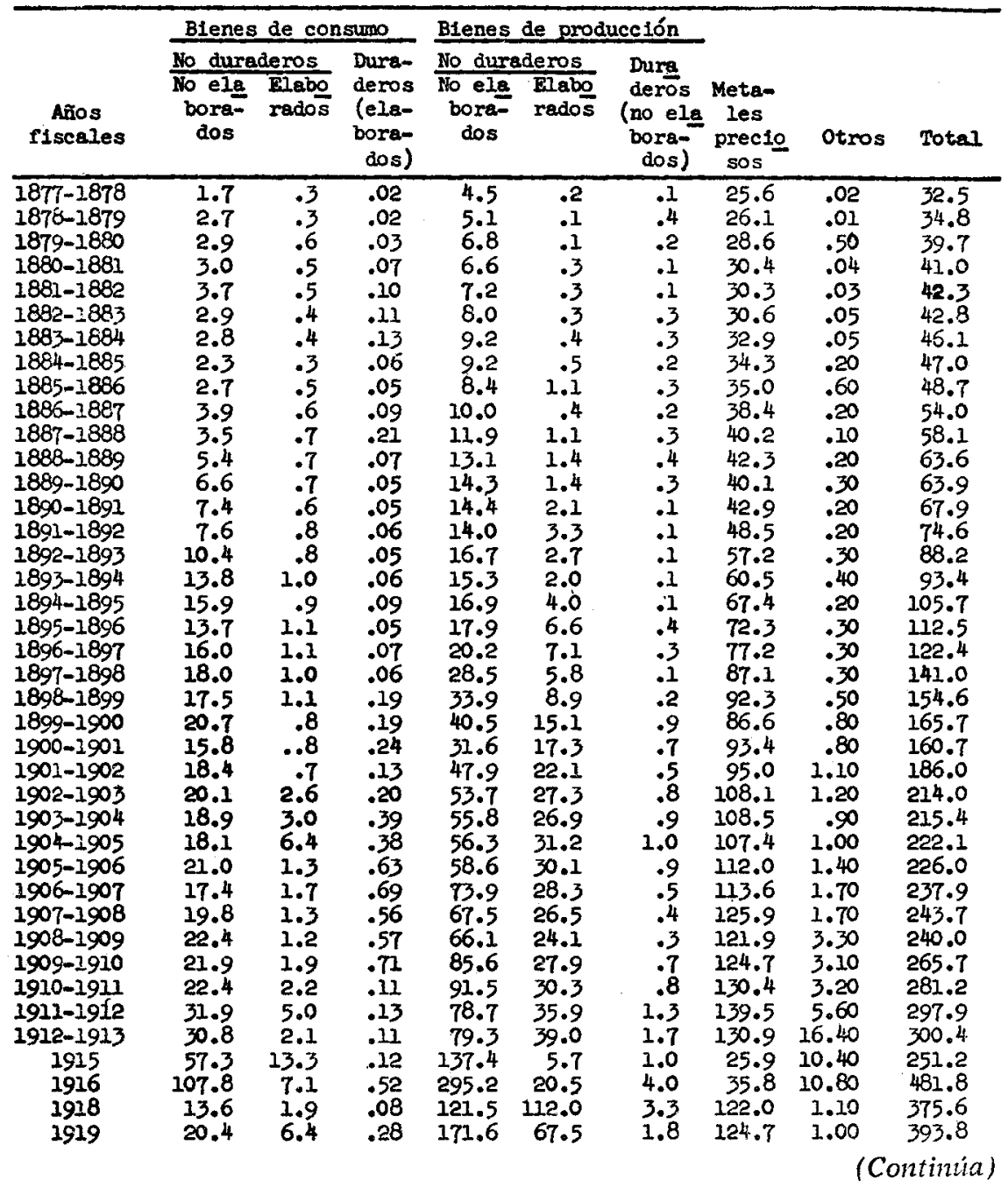




\section{Cuadro 2 (Continuación)}

\begin{tabular}{|c|c|c|c|c|c|c|c|c|c|}
\hline \multirow[b]{3}{*}{$\begin{array}{c}\text { Ar̃os } \\
\text { fiscales }\end{array}$} & \multicolumn{3}{|c|}{ Bienes de consumo } & \multicolumn{3}{|c|}{ Bienes de producción } & \multirow[b]{3}{*}{$\begin{array}{l}\text { Meta- } \\
\text { les } \\
\text { precio } \\
\text { sos }\end{array}$} & \multirow[b]{3}{*}{ Otros } & \multirow[b]{3}{*}{ Total } \\
\hline & \multicolumn{2}{|c|}{ No curaderos } & \multirow[b]{2}{*}{$\begin{array}{l}\text { Dura- } \\
\text { deros } \\
\text { (ela- } \\
\text { bora- } \\
\text { dos) }\end{array}$} & \multicolumn{2}{|c|}{ No duraderos } & \multirow[b]{2}{*}{$\begin{array}{l}\text { Dure } \\
\text { deros } \\
\text { (no ela } \\
\text { bore- } \\
\text { dos) }\end{array}$} & & & \\
\hline & $\begin{array}{l}\text { lo ela } \\
\text { bora- } \\
\text { dos }\end{array}$ & $\begin{array}{l}\text { Elabo } \\
\text { rados }\end{array}$ & & $\begin{array}{c}\text { No ela } \\
\text { bora- } \\
\text { dos }\end{array}$ & $\begin{array}{l}\text { Elabo } \\
\text { rados }\end{array}$ & & & & \\
\hline 1920 & 21.7 & 21.5 & .24 & 368.6 & 307.4 & .6 & 133.9 & 1.10 & 855.3 \\
\hline 1921 & 13.2 & .4 & .01 & 358.6 & 290.7 & .01 & 89.8 & 4.80 & 757.6 \\
\hline 1922 & 23.8 & .7 & .03 & 236.4 & 268.7 & .05 & 109.9 & 4.20 & 543.7 \\
\hline 1923 & 27.9 & 2.9 & .01 & 184.1 & 230.6 & .04 & 116.7 & 6.0 & 568.5 \\
\hline 1924 & 33.9 & 4.2 & .01 & 227.4 & 222.5 & .02 & 122.2 & 4.2. & 614.7 \\
\hline 1925 & 100.9 & 3.0 & 3.59 & 161.2 & 272.6 & .07 & 135.8 & 5.2 & 682.3 \\
\hline 1926 & 127.9 & 3.2 & 5.01 & 115.9 & 299.5 & .05 & 137.5 & 4.80 & 532.9 \\
\hline 1927 & 94.8 & 2.5 & 2.0 & 240.1 & 210.3 & .1 & 85.4 & & 635.2 \\
\hline 1928 & 94.9 & 1.4 & 1.0 & 219.3 & 284.9 & .1 & 88.4 & 2.4 & 592.4 \\
\hline I. & 77.2 & 1.8 & 1.0 & 206.9 & 208.2 & .1 & 93.5 & 1.9 & 0.7 \\
\hline 1930 & 80.0 & 2.8 & 2.7 & 130.4 & 162.9 & 4.8 & 72.9 & 1.1 & 457.6 \\
\hline 1931 & 52.1 & 6.9 & 1.9 & 64.4 & 143.4 & .9 & 128.4 & .6 & 398.7 \\
\hline 1932 & 44.9 & 4.2 & 2.8 & $5 j .6$ & 98.8 & .9 & 97.5 & 1.4 & 304.2 \\
\hline 1935 & 49.5 & 8.1 & 5.1 & 60.2 & 137.8 & 1.6 & 100.9 & .8 & 3.9 \\
\hline 1934 & 57.2 & 5.0 & 2.9 & 227.6 & 229.2 & 4.2 & 116.4 & - & 643.2 \\
\hline 1935 & 66.7 & 3.9 & 4.6 & 343.8 & 266.3 & 6.2 & 58.3 & .8 & 750.6 \\
\hline & 66.1 & 3.7 & 4.9 & 335.9 & 248.4 & 6.7 & 109.5 & .7 & 775.9 \\
\hline & 74.9 & 5.1 & 5.2 & 357.9 & 335.9 & 8.4 & 99. & 4.7 & \\
\hline 1938 & 65.7 & 5.1 & 5.7 & 369.7 & 242.1 & 8.5 & 135.3 & 5.8 & 838.0 \\
\hline 1939 & 35.9 & 19.1 . & 4.9 & 337.0 & 267.5 & 9.6 & 142.8 & 10.2 & 914.2 \\
\hline 10 & 72.7 & 18.0 & 5.4 & 377.3 & 264.6 & 21.4 & 199.7 & .1 & 959.3 \\
\hline 1941 & 96.3 & 22.6 & 10.3 & 316.7 & 184.6 & 34.9 & 63.2 & .2 & 8.9 \\
\hline 1942 & 114.2 & 36.9 & 22.5 & 339.6 & 236.8 & 56.5 & 137.7 & 45.7 & 989.9 \\
\hline $194 \%$ & 186.9 & 96.6 & 90.7 & 355.7 & 303.9 & 74.8 & 12.7 & 8.8 & 1128.8 \\
\hline 1944 & 149.2 & 102.6 & 67.6 & 356.7 & 284.2 & 72.6 & 10.9 & 2.0 & 104 \\
\hline 1945 & 167.3 & 127.5 & 92.8 & 327.8 & 433.8 & 86.7 & 31.2 & 4.8 & 1271.8 \\
\hline 2946 & 199.5 & 154.3 & 183.1 & 456.3 & 513.6 & 99.9 & 285.6 & 22.9 & 19. \\
\hline 1947 & 79.1 & 215.9 & 27.9 & 543.4 & 857.8 & 105.5 & 320.1 & 11.2 & 2160. \\
\hline & 98.5 & 552.1 & 27.6 & 585.9 & 1098.5 & 98.7 & 190.9 & 9.1 & 2661.3 \\
\hline 1949 & 382.3 & 636.3 & 36.0 & 963.7 & 965.2 & 77.7 & 438.6 & 126.4 & 3625.7 \\
\hline 1950 & 473.8 & 532.9 & 43.5 & 1452.2 & 1170.2 & 118.7 & 286.8 & 266.6 & 4344.8 \\
\hline 1951 & 637.3 & 436.1 & 52.2 & 1883.9 & 1532.3 & 89.1 & 535.6 & 283.7 & 5450.2 \\
\hline 1952 & 664.6 & 408.5 & 58.9 & 2069.4 & 1479.8 & 86.1 & 287.4 & 82.3 & $\begin{array}{lll}5 & 137.1\end{array}$ \\
\hline & 802.7 & 438.0 & 69.7 & 1770.6 & 1273.9 & 84.2 & 222.4 & 40.2 & 4701.8 \\
\hline 1954 & 973.2 & 379.4 & 118.2 & 2439.8 & 2735.5 & 82.1 & 407.5 & 211.0 & 6346.8 \\
\hline 1955 & 1409.9 & 508.5 & 193.2 & 3301.1 & & 100.4 & 575.6 & 409.0 & 8846.6 \\
\hline 1956 & 1302.5 & 570.6 & 271.4 & 3661.1 & 2387.8 & 147.1 & 346.4 & 470.9 & 9057.9 \\
\hline 1957 & 1663.7 & 754.5 & 166.8 & 2555.0 & 1994.2 & 172.5 & 354.0 & 319.7 & 7980.6 \\
\hline 1958 & I 517.6 & 1005.2 & 164.7 & 2671.9 & 1469.2 & 233.2 & 335.4 & 381.8 & \\
\hline 1950 & 1383.0 & 1080.9 & 205.9 & 3059.5 & 1580.2 & 216.1 & 446.1 & 409.3 & 8381.2 \\
\hline 1960 & 1738.8 & 1576.4 & 215.5 & 2688.7 & 1450.5 & 209.5 & 313.4 & 454.2 & 8657.2 \\
\hline
\end{tabular}

Fuentes: Estadísticas económicas del Porfiriato. Comercio exterior de México (1877-1911), El Colegio de México, 1960; Anuarios del comercio exterior de los Estados Unidos Mexicanos, Secretaría de Industria y Comercio (antes Secretaria de la Economía Nacional).

En 1900, el $56 \%$ de la mano de obra estaba ocupada en la agricultura; esto hacía que la distribución del ingreso fuera marcadamente desigual. La retribución al trabajo bajó en términos reales y propició un uso abundante del trabajo manual y pocos cambios tecnológicos en las zonas densamente pobladas. La produción agrícola - no estimulada por la demanda del mercado externo ni por la demanda urbana de materias primas - mostró una rígida oferta de productos alimenticios. 


\section{Cuadro 3}

MÉxico: Participación DE CADa GRUPO DE PRODUCtos EN el total DE LAS EXPORTACIONES, 1877-78 A 1960

(Porcientos del total)

\begin{tabular}{|c|c|c|c|c|c|c|c|c|c|}
\hline $\begin{array}{c}\text { Años } \\
\text { ifscales }\end{array}$ & Total & $\begin{array}{l}\text { Bienes } \\
\text { de con- } \\
\text { sumo no } \\
\text { durade- } \\
\text { ros no } \\
\text { elabore } \\
\text { dos } \\
\end{array}$ & $\begin{array}{l}\text { Bienes } \\
\text { de con } \\
\text { sumo no } \\
\text { durade- } \\
\text { ros ela } \\
\text { borados }\end{array}$ & $\begin{array}{l}\text { Bienes } \\
\text { de con } \\
\text { sumo du } \\
\text { raderos }\end{array}$ & $\begin{array}{l}\text { Blenes } \\
\text { de pro } \\
\text { ducción } \\
\text { no dure } \\
\text { deros } \\
\text { no ela- } \\
\text { borados }\end{array}$ & $\begin{array}{c}\text { Bienes } \\
\text { de pro } \\
\text { ducción } \\
\text { no dure } \\
\text { deros } \\
\text { elabora } \\
\text { dos } \\
\end{array}$ & $\begin{array}{c}\text { Bienes } \\
\text { de pro } \\
\text { duccion } \\
\text { durade- } \\
\text { ros } \\
\end{array}$ & $\begin{array}{l}\text { Meta } \\
\text { les } \\
\text { pre- } \\
\text { plo- } \\
\text { clos }\end{array}$ & Otros \\
\hline $1877-1878$ & 100.0 & 5.3 & 1.0 & 0.1 & 14.0 & 0.6 & 0.3 & 79.0 & 0.2 \\
\hline $1890-1891$ & 100.0 & 11.0 & 1.0 & 0.1 & 21.0 & 3.0 & 0.1 & 63.0 & 0.3 \\
\hline $1900-1901$ & 100.0 & 10.0 & 0.5 & 0.1 & 20.0 & 11.0 & 0.4 & 58.0 & 0.5 \\
\hline $1910-1911$ & 100.0 & 8.0 & 0.8 & 0.1 & 32.0 & 11.0 & 0.3 & 46.0 & 1.0 \\
\hline 1920 & 100.0 & 2.5 & 2.5 & 0.1 & 43.0 & 36.0 & 0.1 & 15.0 & 0.2 \\
\hline 1930 & 100.0 & 17.0 & 0.6 & 0.6 & 28.0 & 35.0 & 1.0 & 16.0 & 0.2 \\
\hline 2940 & 100.0 & 7.0 & 2.0 & 0.6 & 39.0 & 27.0 & 2.0 & 21.0 & - \\
\hline 1950 & 100.0 & 21.0 & 12.0 & 1.0 & 33.0 & 27.0 & 3.0 & 6.6 & 6.0 \\
\hline 1960 & 100.0 & 20.0 & 18.0 & 2.5 & 31.0 & 17.0 & 2.4 & 3.6 & 5.0 \\
\hline
\end{tabular}

Fuentes: Estadisticas económicas del Porfiriato. Comercio exterior de México (1877-1911), El Colegio de México, 1960; Anuarios del comercio exterior de los Estados Unidos Mexicanos, Secretaría de Industria y Comercio (antes Secretaría de la Economía Nacional).

Frente al crecimiento de la población, la producción de alimentos por habitante disminuyó; en el caso del maíz el descenso fue de 282 kilogramos por persona en 1877 a 144 en 1907, o. sea $49 \%$. La inversión extranjera fue poco importante en el sector agropecuario. Pese a que se hicieron concesiones de grandes áreas de tierras cercanas a la frontera norte a extranjeros, éstas no afectaron gran cosa el comportamiento del sector, si bien fueron causa de dificultades años después.

Durante el Porfiriato, la producción para la exportación tuvo una influencia muy dinámica en el comportamiento de la producción minera e hizo que se registrara un cambio importante en la naturaleza de estas exportaciones. A principios del Porfiriato, México era principalmente exportador de oro y plata; hasta comienzos de la década de 1890 , la producción de metales preciosos dominó la actividad minera nacional, pero en ese decenio se inició el auge de los minerales industriales. El desarrollo de los combustibles, el fierro y el granito determinaron su crecimiento, en tanto que las bajas en las cotizaciones de la plata desanimaron la producción de este metal. El número de trabajadores ocupados en la actividad minerometalúrgica aumentó a una tasa anual dél $1.6 \%$ de 1895 a 1907, superior al crecimiento de la población total. Su productividad se elevó notablemente, de 17.8 toneladas por trabajador en 1897 a 48.0 en 1907. Durante ese lapso el jornal mínimo en la misma rama productiva subió de 35 a 82 centavos diarios. 
La inversión extranjera fue decisiva en la minería. El Código Minero de 1894 hizo posible que los extranjeros adquirieran bienes inmuebles en las zonas fronterizas, facilitando el establecimiento de explotaciones mineras en el norte de la República.

La producción minera trajo aparejada la demanda de algunos bienes de producción y de consumo, y a la vez el crecimiento industrial estimuló el desarrollo minero y agropecuario. El fortalecimiento de la industria nacional influyó en otras actividades de dos formas, produciendo bienes que les eran necesarios y demandando sus productos.

La industrialización del país se basó en la producción para el mercado interno. Las inversiones extranjeras y las exportaciones fortalecieron la demanda agregada y propiciaron aumentos en el consumo de productos manufacturados. Las inversiones extranjeras no sólo apoyaron el proceso de formación de capital en la industria, sino que fueron decisivas en las comunicaciones y en la minería. La construcción de ferrocarriles se financió con ahorro externo. Su época de rápido crecimiento se inició en el decenio de 1880 , al finalizar el cual existían 9544 kilómetros de líneas férreas y se contaba con las principales troncales y líneas secundarias del actual sistema ferroviario del país.

México se encontraba hacia 1890 en pleno desarrollo industrial. Antes de 1888, cuando la inversión extranjera en el sector industrial fue limitada, ${ }^{4}$ el crecimiento de la producción industrial se basó en una mayor ocupación de la fuerza de trabajo y en uso más intenso del equipo; pero a partir de 1889 la inversión extranjera en este campo se incrementó con vigor y aumentó la inversión en maquinaria por fábrica. Aparecieron fábricas modernas en diversas actividades: tejidos de algodón, lana, pastas y conservas alimenticias, plantas vitivinícolas, cervecerias, cigarrillos y puros, imprenta, productos químicos, etc., que en buena parte procesaron materias primas de origen agrícola.

La demanda industrial de insumos originó cambios en la estructura de la producción de otros sectores y dio lugar a la sustitución de algunas importaciones. Así, las materias primas no elaboradas descendieron del 54 al $15 \%$ del total de las materias primas importadas; esto se puede ilustrar con el crecimiento de la producción interna de algodón, que sustituyó a la fibra importada. El auge de las manufacturas tuvo el efecto de inducir aumentos en el consumo de materias primas elaboradas y explica su mayor importancia en la importación total de materias primas (del 45 al $85 \%$ del total). Este fue el caso de las anilinas y de otros productos químicos para la industria textil, de los artículos de metal, de las materias para la producción de alimentos, bebidas, vestido, etc. (Véase el cuadro 4.)

El desarrollo industrial y de los transportes trajo consigo una diversificación de las importaciones. Creció la importancia de la de bienes de capital, que pasaron del $26.6 \%$ del total en $1888-89$ al $29.9 \%$ al final del Porfiriato. Al igual que en Inglaterra en una fase similar, los precios de los bienes industriales descendieron entre 1890 y 1911 .

4 La propiedad del $71 \%$ del capital invertido en la industria y en la creación de nuevas sociedades, entre 1886 y 1910, pertenecía a mexicanos. 


\section{Cuadro 4}

MÉXICO: IMPORTACIONES A PRECIOS CORRIENTES, 1888-89 A 1960 (Millones de pesos)

\begin{tabular}{|c|c|c|c|c|c|c|}
\hline $\begin{array}{c}\text { Años } \\
\text { fiscales }\end{array}$ & $\begin{array}{l}\text { Bienes de } \\
\text { To durade- } \\
\text { ros }\end{array}$ & $\begin{array}{c}\text { consumo } \\
\text { Durade- } \\
\text { ros }\end{array}$ & 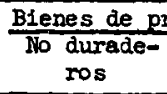 & $\begin{array}{c}\text { oducclón } \\
\text { Durade- } \\
\text { ros }\end{array}$ & Total & Otros \\
\hline $\begin{array}{l}1888-1889 \\
1889-1890 \\
1892-1893 \\
1893-1894 \\
1894-1895 \\
1895-1896 \\
1896-1897 \\
1897-1898 \\
1898-1899 \\
1899-1900 \\
1900-1901 \\
1901-1902 \\
1902-1903 \\
1903-1904 \\
1904-1905 \\
1905-1906 \\
1906-1907 \\
1907-1908 \\
1909-1910 \\
1910-1911\end{array}$ & $\begin{array}{l}20.1 \\
22.8 \\
30.3 \\
21.6 \\
24.4 \\
30.0 \\
33.0 \\
30.9 \\
34.7 \\
37.8 \\
37.5 \\
42.9 \\
51.6 \\
49.7 \\
48.4 \\
57.1 \\
61.1 \\
63.0 \\
64.4 \\
68.2\end{array}$ & $\begin{array}{l}5.3 \\
6.1 \\
5.3 \\
5.5 \\
6.8 \\
7.9 \\
7.9 \\
9.7 \\
10.9 \\
13.6 \\
13.2 \\
14.1 \\
16.8 \\
19.1 \\
21.8 \\
20.5 \\
24.3 \\
24.3 \\
18.6 \\
23.0\end{array}$ & $\begin{array}{l}14.2 \\
14.4 \\
16.5 \\
17.3 \\
21.4 \\
21.5 \\
22.5 \\
25.9 \\
29.5 \\
34.5 \\
38.2 \\
44.8 \\
57.3 \\
54.8 \\
50.9 \\
50.1 \\
52.9 \\
56.6 \\
52.9 \\
54.7\end{array}$ & $\begin{array}{l}14.3 \\
23.4 \\
13.1 \\
11.5 \\
13.9 \\
18.6 \\
19.6 \\
28.0 \\
32.5 \\
42.6 \\
40.6 \\
44.0 \\
61.4 \\
51.7 \\
48.9 \\
52.4 \\
72.5 \\
72.9 \\
57.6 \\
62.2\end{array}$ & $\begin{array}{l}53.9 \\
67.7 \\
65.2 \\
56.0 \\
66.6 \\
78.0 \\
82.9 \\
94.6 \\
107.6 \\
128.6 \\
129.6 \\
145.9 \\
187.1 \\
175.2 \\
170.0 \\
180.1 \\
210.8 \\
216.9 \\
193.5 \\
208.1\end{array}$ & \\
\hline $\begin{array}{c}1938-1939 \\
1940 \\
1941 \\
1942 \\
1943 \\
1944 \\
1945 \\
1946 \\
1947 \\
1948 \\
1949 \\
1950 \\
1951 \\
1952 \\
1953 \\
1954 \\
1955 \\
1956 \\
1957 \\
1958 \\
1959 \\
1960\end{array}$ & $\begin{array}{r}36.9 \\
22.4 \\
56.9 \\
53.6 \\
103.8 \\
262.1 \\
223.6 \\
361.7 \\
296.1 \\
250.5 \\
267.4 \\
377.8 \\
1125.6 \\
1355.3 \\
1121.1 \\
787.0 \\
627.6 \\
904.8 \\
1343.8 \\
1286.6 \\
788.5 \\
871.6\end{array}$ & $\begin{array}{ll} & 167.3 \\
& 172.0 \\
224.8 \\
\\
167.0 \\
169.1 \\
215.0 \\
278.5 \\
\\
549.1 \\
746.6 \\
488.8 \\
& 538.2 \\
& 608.2 \\
& 809.1 \\
& 769.3 \\
& 706.3 \\
& 883.2 \\
1 & 008.8 \\
1 & 194.9 \\
1 & 332.4 \\
1 & 497.9 \\
1 & 614.4 \\
1 & 738.5\end{array}$ & $\begin{array}{ll} & 185.9 \\
208.6 \\
253.9 \\
248.3 \\
260.9 \\
\\
371.8 \\
382.1 \\
\\
499.8 \\
589.5 \\
\\
587.3 \\
745.3 \\
& 891.5 \\
1 & 149.8 \\
1 & 034.6 \\
1 & 954.3 \\
3 & 101.8 \\
4 & 106.5 \\
4 & 705.5 \\
4 & 992.9 \\
4 & 706.2 \\
4 & 516.4 \\
4 & 991.1\end{array}$ & $\begin{array}{ll} & 170.5 \\
202.4 \\
308.3 \\
\\
214.8 \\
246.6 \\
\\
378.3 \\
& 595.9 \\
1 & 071.7 \\
1 & 386.6 \\
1 & 410.4 \\
1 & 680.5 \\
2 & 030.7 \\
1 & 981.8 \\
1 & 873.2 \\
2 & 937.3 \\
3 & 725.8 \\
4 & 522.9 \\
6 & 193.3 \\
6 & 698.9 \\
6 & 552.3 \\
5 & 582.3 \\
7 & 205.9\end{array}$ & 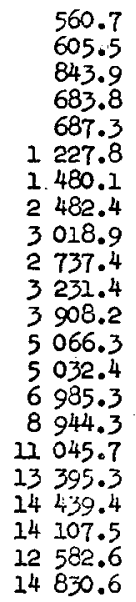 & $\begin{array}{l}71.3 \\
64.5 \\
78.9 \\
23.3\end{array}$ \\
\hline
\end{tabular}

Fuentes: Estadísticas económicas del Porfiriato. Comercio exterior de México (1877-1911), El Colegio de México, 1960; Anuarios del comercio exterior de los Estados Unidos Mexicanos, Secretaría de Industria y Comercio (antes Secretaría de la Economía Nacional).

posiblemente debido a ascensos de la productividad, ya que los precios de los bienes de inversión y de los intermedios importados se movieron en forma un tanto errática.

En general, 1890 es el año en que la economía mexicana muestra características que a la postre resultaron permanentes. Ese año se 
terminaron las líneas troncales ferroviarias más importantes, las nuevas comunicaciones reorientaron el comercio exterior, y por primera vez se enviaron tres cuartas partes de las exportaciones totales a Estados Unidos. Considerando también la cuantía de la inversión norteamericana en México, el país reflejó, ese año, la estrecha dependencia que con esa economía ha conservado hasta nuestros días.

Durante el último decenio del siglo XIX, el crecimiento industrial fue vigoroso y las industrias obtuvieron altas tasas de utilidades. Éste fue el decenio florido del Porfiriato. Se sustituyeron importaciones en las industrias de cemento, dinamita y siderurgia. La industria del tabaco, la siderurgia, la producción de vidrio plano, la de vasijas y diversos recipientes, tuvieron un fuerte crecimiento. También los espejos y otros productos de vidrio fueron incrementando su valor y mejorando los acabados desde 1890. En esos años ya se apreciaba que la demanda de artículos de fierro y acero era de bastante consideración.

Sin embargo, también a partir de 1890 se inició un proceso de alza de los costos industriales por aumento de los precios de las materias primas de producción interna y de los bienes de producción importados. Dicho proceso obstaculizó un crecimiento más rápido de la producción industrial. Más aún, algunos salarios en la industria tendieron a ascender. No obstante, a finales del Porfiriato, sobre todo en el último decenio, se aprecia un conjunto de elementos que evidencian un proceso de disminución del ingreso real de la mano de obra que restó dinamismo a la demanda interna e influyó para que las industrias de consumo vieran limitada su expansión.

Los artesanos que cerraban sus talleres, impotentes frente a la competencia de las modernas instalaciones industriales, pasaban a engrosar la fuerza de trabajo industrial. A partir de 1895, bien fuera por el posible aumento de la relación capital-producto, o porque el proceso de inversión no fue lo bastante ágil, la mano de obra ocupada en la industria creció a una tasa del $1.0 \%$, menor ésta que la del incremento de la población urbana, que fue de $1.2 \%$ aproximadamente. Aun cuando en el decenio de los años ochenta el número de telares se duplicó en la industria textil, el de obreros ascendió sólo $35 \%$. Al parecer, el desarrollo industrial era insuficiente para dar ocupación productiva al incremento de la fuerza de trabajo.

Una vez que la reforma monetaria de 1905 e influencias de otra índole eliminaron el efecto protector de la depreciación de la plata, que había operado desde el siglo anterior, las oscilaciones cíclicas hicieron inestable el sistema económico; por ejemplo, en 1907-1908 se presentaron acumulaciones de existencias.

Cabe señalar también que la tendencia a la mayor desigualdad en la distribución del ingreso resultaba, al menos en parte, de la incapacidad de absorber mano de obra en proporción igual o superior al crecimiento de la población y, además, porque existía un proceso de concentración monopólica que afirmaba el deterioro de la participación del factor trabajo en la distribución del ingreso. El supuesto de una mayor desigualdad de la distribución se confirma por la disminución del consumo aparente de ciertos bienes como algodón, azúcar, piloncillo y tabacos labrados, e inclusive sugiere la posibilidad de 
una disminución absoluta en el nivel de ingreso real de partes importantes de la fuerza de trabajo. En efecto, a finales de siglo se detuvo el proceso de aumento de los salarios, y de 1897 a 1910 éstos descienden de 92 a 36 centavos en términos reales, es decir, a precios constantes.

Al parecer hubo un incremento de la relación capital-producto, justamente cuando las posibilidades de sustitución de importaciones más obvias se estaban agotando. Fue éste el caso de las telas de algodón. Esta rama industrial perdió ímpetu al terminarse la sustitución de importaciones y tuvo que depender, desde entonces, del crecimiento de la demanda, la cual se vio reducida por el deterioro de la distribución del ingreso. La falta de una demanda interna dinámica impidió que se dieran nuevos estímulos al proceso de industrialización; la fabricación interna de maquinaria, por ejemplo, no llegó a alcanzar una escala industrial competitiva y se tuvo que depender del suministro de estos productos del exterior y por tanto del comportamiento de la capacidad para importar.

El volumen de mano de obra ocupada en las manufacturas, entre 1895 y 1910, aumentó sólo $10 \%$, tasa menor que la del crecimiento de la población y bastante inferior a la del $1.3 \%$ de crecimiento anual correspondiente a la ocupada en la agricultura. Este fenómeno marca una de las grandes interrogantes del Porfiriato. ¿Por qué ascendió la participación de la fuerza de trabajo agrícola dentro de la mano de obra total? Mientras tanto, de 1900 a 1910, la población urbana ascendió $1.2 \%$ anual y la rural $1.0 \%$ anual. ${ }^{5}$ En algunas industrias hubo disminución, en términos absolutos, de la mano de obra ocupada, por ejemplo, en las siguientes: tabaco, química, platería, joyería y relojería. El personal aumentó poco en otras, tales como la del vestido y el calzado, alimentos y bebidas, y materiales para construcción, entre otras. En las industrias de la madera, artes mecánicas y gráficas y productos metálicos el personal ocupado aumentó, pero la mayor demanda de mano de obra de estas últimas no fue suficiente para absorber el crecimiento natural de la fuerza de trabajo que resultaba del aumento de la población, y menos aún para disminuir la súbocupación. El Porfiriato, en gran medida si no es que principalmente, parece haber llegado a su fin como resultado de una "trampa" malthusiana; es decir, la producción se concentraba en fábricas que absorbían poca fuerza de trabajo como resultado del mayor uso de maquinaria que a su vez ahorraba mano de obra en el proceso productivo, y por la tendencia a la concentración monopólica. Concomitantemente, desapare-

5 Es interesante observar las distintas tasas de crecimiento demográfico urbano de 1900 a 1910, según el tamaño de la población, casi nulas en las pequeñas y aceleradas en las grandes: de 2501 a 5000 habitantes, $0.2 \%$ anual; de 5000 a $10000,0.1 \%$; de 10001 a $20000,1.2 \%$; de 20000 a $50000,2.9 \%$; de 50001 a 100000 , $2.6 \%$, y de más de $100000,2.9 \%$. Es posible concebir el desplazamiento de la población como dos pasos distintos del mismo proceso: a) el movimiento del campo a las pequeñas poblaciones cercanas, y $b$ ) el de estas últimas a las ciudades. El Porfiriato impidió el primero pero no el segundo, lo que explica el escaso crecimiento de las poblaciones de menos de 20000 habitantes. Esto tuvo gran importancia después, durante el desarrollo postrrevolucionario, ya que fueron las ciudades de mayor tamaño los centros en que florecieron la industria y los servicios. 
cían muchos talleres artesanales cuyos trabajadores engrosaban las filas de los desocupados. Entre 1895 y 1910 las manufacturas incrementaron su demanda de mano de obra únicamente en 52000 obreros. Los principios liberales de que se nutría el porfirismo impedían una acción correctiva por parte del Estado, y las fuerzas del mercado operaban en el sentido de reducir el ingreso real del trabajador sin propiciar aumentos de la ocupación.

Política económica. ¿Cuáles fueron los rasgos más destacados de la política económica del Porfiriato? Desde la República Restaurada, el arancel se usó como instrumento de protección industrial, y otro tanto se hizo durante el Porfiriato, pero ahora complementado con fraquicias y concesiones de diversa índole, tales como exenciones de impuestos federales, importación de maquinaria libre de derechos, etc.; políticas que habrían de continuar también los gobiernos revolucionarios a lo largo del siglo xx. Fueron eliminadas también viejas trabas coloniales a la libertad mercantil, así como suprimida la organización gremial de las manufacturas y abolidos determinados impedimentos de tipo fiscal, como las alcabalas. Todo esto, al apoyar la sustitución de importaciones, dio alientos a la produción agrícola y a la industrial, proceso que fue estimulado, además del manejo arancelario, por la depreciación de la plata. Los aranceles hacian entrar en conflicto los intereses de industriales y agricultores, y recuerdan, aunque intercambiados los sectores, los argumentos utilizados en las discusiones de las "leyes de granos" inglesas de mediados del siglo xix. Durante el Porfiriato se inició la nacionalización de los ferrocarriles, con la. adquisición, entre otros, del Interocéanico y del Central, y se fundó el primer banco de fomento; sobre todo, se saneó la hacienda pública. Hubo también ahorros en los gastos corrientes y consolidaciones de deuda que aminoraron el peso del servicio anual. Como el desarrollo económico alcanzado favoreció las recaudaciones de impuestos, se hizo posible la eliminación de las alcabalas, que entorpecían el comercio, variaban de un Estado a otro y significaban discriminación a favor de artículos importados.

Los años finales del Porfiriato. En los primeros años del siglo $\mathrm{xx}$ era patente la debilidad económica del sistema productivo que constituyó el Porfiriato. Dejaron de actuar factores que, hasta entonces, estimularon el crecimiento industrial, especialmente en el decenio anterior. El precio de la plata dejó de descender y fluctuó erráticamente. Después, a partir de 1905, la reforma monetaria fijó el tipo de cambio e inclusive existió un pequeño movimiento de revaluación, de manera que la anterior protección que ejercía el mercado cambiario dejó de favorecer la producción interna y de estimular el crecimien. to de las exportaciones. La relación de precios del intercambio entró en un descenso que se prolongó por el resto del período y redujo la capacidad para importar, entorpeciendo el proceso de capitalización del país. Además, al principio del siglo se habían agotado ya las posibilidades más fáciles de sustituir importaciones, las que, aun cuando habían influido en la produción de materias primas de origen agropecuario y de artículos manufacturados producidos por la industria 
ligera, no lograron llegar a la etapa de sustitución de materias primas y bienes de capital en escala suficiente para sostener el proceso de industrialización. La continuación del proceso de sustitución de importaciones hubiera requerido un mercado más amplio que permitiera la fabricación de bienes de consumo duradero, y una fuerte demanda de materias primas y maquinaria que facilitara su producción a precios competitivos o superiores a los precios internacionales en un margen moderado; aunque desde un punto de vista tecnológico es de dudar que en un país en el que la educación era un lujo hubiera sido posible producir bienes intermedios y maquinaria y equipo cuyos grados de complejidad necesitan un amplio número de técnicos $\mathrm{y}$ abundante mano de obra especializada.

$\mathrm{La}$ tendencia de las inversiones y las necesidades que planteaba la continuación del desarrollo industrial sugieren la presencia de un aumento de la relación capital-producto. Dicho cambio era difícil de llevarse a cabo en una economía con relación de intercambio en tendencia desfavorable y con elevada propensión al consumo, tanto de las clases de bajos ingresos como de los grupos de altos ingresos. En estas condiciones era poco lo que podían lograr los aranceles y subsidios y las otras débiles medidas de política económica para contrarrestar los perjuicios que causaba el sector externo y los obstáculos que planteaba la continuación del desarrollo económico. Perdida la dinámica del comercio exterior, el mercado interno habría podido estimular el desarrollo industrial. Sin embargo, el proceso hacia una mayor desigualdad de la distribución del ingreso provocaba que la demanda interna cambiara en forma muy poco dinámica y no constituyera un estímulo suficiente para la inversión. Por otra parte, las utilidades de las empresas que debieron haber sido favorecidas por el anterior aumento de precios, resultado de la depreciación de la plata, dejaron de recibir este elemento de estímulo conforme el tipo de cambio se estabilizó.

Siendo el nivel de inversión insuficiente para absorber el crecimiento de la mano de obra, lo era menos aún para eliminar la sub. ocupación y la baja productividad que imperaba en muchas actividades urbanas y rurales. Esto influyó para que el crecimiento del volumen de mano de obra hiciera más difíciles las condiciones del mercado de trabajo y favoreciera la disminución del ingreso real de los trabajadores. El descenso del costo de la mano de obra no operaba como un estímulo al aumento de la ocupación a causa de la poca dinámica de la demanda, la falta de una clase empresarial que aprovechara las variaciones de los precios relativos de los insumos y la rigidez -poca movilidad geográfica- del mercado de trabajo.

El gran problema del Porfiriato lo constituyó el sector agropecuario. La forma de operación del latifundio encajonó a la mano de obra e hizo difícil la transferencia de población de unas zonas rurales a otras y del campo a la ciudad. Esto se aprecia por el poco crecimiento de las ciudades de menos de 20000 habitantes. En otras palabras, el mercado de trabajo se hizo rígido e impidió la movilidad de la mano de obra.

Pese a que la agricultura de exportación, sobre todo la del norte y la de Yucatán, mostró dinamismo, el sector en conjunto se mantuvo prácticamente estancado y la producción de alimentos creció a una 
tasa menor que la de la población, de tal manera que el consumo per capita de artículos de la dieta popular disminuyó.

Es posible apuntar una hipótesis acerca del efecto que tuvo el conjunto de factores antes mencionado. Se ha afirmado que la capacidad de crecimiento de una economía subdesarrollada está determinada por la producción de alimentos, que permite sostener aquella parte de los habitantes que se dedica a la industria y a los servicios y promueve el crecimiento industrial y mercantil del país, la diversificación de la estructura productiva y el aumento de la productividad. Cuando la producción de alimentos es insuficiente, el crecimiento del ingreso que produce el desarrollo industrial implica aumentos del consumo que tienen que satisfacerse con importaciones. En el caso del Porfiriato esto se dificultaba, toda vez que el desarrollo industrial se orientó hacia el mercado interno y las exportaciones de productos mineros y agropecuarios eran necesarias para financiar las importaciones de materias primas, maquinaria y equipo que requería el propio desarrollo industrial. Si la importación de alimentos se hubiera incrementado habria tenido que disminuir la importación de equipo y, de cualquier manera, se obstaculizaría el crecimiento de la capacidad productiva.

El escaso dinamismo del sector agrícola era tanto más grave cuanto que siendo los niveles de ingreso muy bajos, el consumo de alimentos significaba una proporción muy alta del gasto, es decir, la elasticidadingreso del consumo era elevada, así que el aumento del producto nacional influía en crecimientos considerables de la demanda de alimentos, ante la cual la falta de espíritu empresarial del latifundista - que se traducía en incapacidad para absorber cambios tecnológicos y elevar la productividad- originaba una respuesta a la producción casi nula y creaba inelasticidad de oferta que impedía un crecimiento sostenido. El deterioro del sector externo impedía a su vez efectuar importaciones para aliviar la inelasticidad de la oferta de productos agrícolas. La desigual distribución del ingreso hacía rígida la importación de bienes suntuarios y restaba flexibilidad a la oferta de bienes importados. Ante el crecimiento de la población, el poco aumento de la ocupación productiva y la imposibilidad del sistema económico para alcanzar nuevamente una dinámica de crecimiento, la disminución del ingreso de las mayorías se afirmó y el descontento se agudizó. El deterioro de la posición de la fuerza de trabajo y su creciente urbanización probablemente estimularon su actuación política. Se iniciaron movimientos de defensa del pueblo y se llegó a las huelgas que, como es sabido, fueron reprimidas brutalmente. Las dificultades en el mercado de trabajo hicieron más intolerable esta situación. La falta de respeto a los derechos humanos y la conducta arbitraria de los dueños de los medios de producción provocaron una situación política explosiva a la que la campaña presidencial de 1910 encendió la mecha. La Revolución terminó con esta época de la vida del país.

\section{Cambios institucionales fUndamentales}

El período armado de la Revolución tuvo un efecto destructivo cuantioso, aunque difícil de precisar, en el capital humano y físico del 
país. Según los censos, la población descendió de 15.2 millones en 1910 a 14.3 millones en 1921 y no es hasta 1925 cuando volvió a alcanzar el nivel que tenía al final del Porfiriato. El sistema de transporte, sobre todo los ferrocarriles, resintió los estragos del movimiento armado. Parece ser que los niveles de producción por persona de 1920 se asemejan a los de 1910, aunque en algunos productos aun los niveles de 1930 resultan inferiores a los de finales del Porfiriato, como en el caso de la cebada en grano, el maíz, el trigo, el chile verde, el tabaco y el café. Otros productos alcanzaron al final del decenio de los veinte un nivel parecido (algodón, caña de azúcar) y algunos mostraron aumentos (arroz, jitomate, plata, azúcar y petróleo, el que creció sin interrupción).

En síntesis, el volumen de la producción total a mediados del decenio de los veintes se aproximaba probablemente a los niveles de finales del Porfiriato. En ese decenio se inicia, entre otras medidas con la fundación del Banco de México y la construcción de caminos y de obras de riego, una política de crecimiento económico coincidente con el hecho de que el sistema económico se responía de los trastornos anteriores. Sin embargo, este proceso fue interrumpido por la gran crisis de 1929-1933. La recuperación posterior se confunde con los efectos de los importantes cambios estructurales ocurridos durante la administración del presidente Cárdenas.

La reforma agraria. Dos preguntas pueden plantearse de inmediato al tratar este tema: ¿Qué condiciones prevalecían en nuestra agricultura antes del reparto de tierras? y ¿qué efectos directos e indirectos tuvo el reparto agrario?

Puede suponerse que antes de la reforma agraria el trabajo agrícola se remuneraba con salario igual a su producto marginal. ${ }^{6}$ Para que esto ocurriera, hay que suponer también que el producto marginal del trabajo era positivo; en otra forma el salario tendría que ser igual al producto medio para que los agricultores pudieran obtener el ingreso de subsistencia. Esto es, el latifundista, bien fuera actuando como empresario o a través de un administrador, maximizaba el ingreso que obtenía de la propiedad de la tierra; sin embargo, el latifundista ausentista minimizaba a su vez el tiempo que permanecía en su propiedad agrícola, tiempo que en general se reducía a la época de cosechas. Por esta razón eran comunes los cultivos de ciclo Iargo, tales como el maguey, el henequén, el café y la caña de azúcar, y así maximizaban ingresos en un sentido estrecho, toda vez que la tierra no era un factor móvil que se asignara a usos más eficientes. En muchos casos se mantenían tierras ociosas que fácilmente podrían haberse cultivado.

La reforma agraria, al convertir a los agricultores en propietarios agrícolas, determinó que el ingreso de los campesinos se igualara al producto medio de su trabajo. Esto no es sino una forma de decir que la distribución de la tierra constituyó una redistribución de ingresos, lo

6 Esta hipótesis, al igual que el análisis posterior de transferencias intersectoriales de recursos, está inspirada en el modelo de John Fei y Gustav Ranis, The Economics of the Labor Surplus Economy, Irwin, 1964. 
que debe de haber ocurrido siempre que el producto medio haya sido superior al marginal. Es concebible además que el producto marginal del trabajo fuera superior a cero. Dos razonamientos apoyan esta última presunción. Primero, la existencia entre los empresarios agrícolas de alrededor de un $15 \%$ de medieros, aparceros, etc., que indica que la distribución del producto se llevaba a cabo entre los propietarios de los factores de acuerdo con condiciones de costo marginal; y segundo, que la población económicamente activa dedicada a la agricultura era de 3.6 millones de personas en 1930, frente a 6.4 millones de personas ocupadas en esta actividad en 1963, estas últimas dedicadas a trabajar un área cultivable mucho mayor. Como esto ha ocurrido también en las áreas de agricultura tradicional caracterizadas por su estancamiento técnico, se deduce que antes de la reforma agraria existía una vasta extensión de tierras susceptibles de cultivarse que no eran trabajadas. Por un lado, significa que si el dueño de la tierra contrataba peones obtenía su beneficio máximo pagando a éstos el producto marginal del trabajo; por otro, que la disponibilidad de tierras de esa época hace inconcebible que el producto marginal del trabajo fuera aproximadamente igual a cero, aunque el bajo índice de innovaciones técnicas significaba que se operaba en condiciones de rendimientos decrecientes. Así pues, el salario igual al costo marginal es una posibilidad lógica, y el producto medio superior al producto marginal lo es igualmente.

La entrega de la tierra significó que su producto total quedara a disposición del ejidatario y, en consecuencia, que el ingreso de éste se igualara al producto medio de su trabajo. De manera que su ingreso aumentó en función de la diferencia entre el producto medio y el marginal del trabajo agrícola. Es posible que el aumento del ingreso, al hacer menos precaria la situación económica del campesino, facilitara que los niños en edad escolar asistieran a las nuevas escuelas rurales, iniciándose el proceso de calificación de la mano de obra agrícola, cuyos efectos, aun cuando son difíciles de cuantificar, deben de haber influido en el posterior aumento de la productividad del sector agropecuario y en su absorción de avances tecnológicos.

La distribución de la tierra liberó al peón acasillado, el cual por primera vez quedó libre de empuñar el arado en el cultivo que más le interesara o de marchar a otros sitios en busca de horizontes más propicios. Se cumplió una de las condiciones previas del desarrollo económico: la movilidad de la mano de obra. Asimismo, en algunas partes se liberó a la tierra de sus cultivos tradicionales y se la destinó a otros que resultaban más productivos, es decir, se siguieron más de cerca las indicaciones y los estímulos del mercado. Aspecto no económico, pero de gran importancia, fue que la reforma agraria liquidara el poder político de la clase latifundista. Esto hizo posible consolidar un grupo político nuevo, el cual, para mantenerse en el poder, tomó como bandera, junto con la reforma agraria, ciertos principios que propiciaron el desarrollo económico, tales como la política de riego, el desarrollo de las comunicaciones y los gastos de salubridad y educación. Se liquidó definitivamente el predominio de la casta identificada con la antigua propiedad de la tierra.

En resumen, desde el punto de vista económico, la reforma agraria 
tuvo dos efectos dominantes a los que llamaremos efecto redistribución y efecto movilidad.

El efecto redistribución modificó la distribución del ingreso y fue cuantitativamente poco importante. En 1939, el producto del sector agropecuario significaba sólo el $23.8 \%$ del producto bruto interno. Ese año, según el Censo Ejidal de 1940, el valor de la producción ejidal constituyó el $54.1 \%$ del valor total de la producción agropecuaria.

Siendo moderado el efecto redistribución, el caso mexicano es poco adecuado para compararse con los de otros países de estructura productiva diferente. Por un lado, en 1936-1940 la economía mexicana distaba mucho de ser una economía predominantemente agraria y el monto de la redistribución estaba condicionado a la participación del sector agropecuario en el producto nacional y a su distribución entre propietarios y asalariados agrícolas. En cambio, en países donde predomina la estructura agraria el efecto redistribución puede ser mayor; pero en ese caso la reforma agraria debe habilitar al sector agrícola a realizar dos funciones que redunden en el desarrollo del país: proveer de mano de obra al resto de la economía y, más tarde, cubrir su propio consumo, y crear un excedente de producción para mantener a la población dedicada a las actividades industriales y de servicios, inclusive aquella que se desplaza de la agricultura hacia zonas urbanas. El excedente productivo se puede extraer a través del sistema impositivo o del mecanismo financiero, invirtiendo los ahorros del sector agrícola en la industria y los servicios. Este excedente transferible, necesario para el desarrollo económico, puede ser menor, igual o mayor que el efecto redistribución del reparto de tierras de cultivo y, dependiendo de su monto, puede aumentar o disminuir el nivel de ingreso real de los campesinos, como resultado de una reforma agraria previa al proceso de desarrollo.

En México el proceso de formación del excedente de producción generado en la agricultura que sostuvo el desarrollo de las actividades urbanas nunca fue muy importante y en todo caso fue anterior a la reforma agraria. Probablemente se produjo durante el Porfiriato y fue aminorado o sustituido por las inversiones extranjeras y el comportamiento del sector minero. Las cifras indican que la estructura productiva se había diversificado desde antes del reparto agrario, así que los sectores industrial y de servicios fueron autosuficientes para su propio desarrollo sin necesidad de recibir recursos transferidos por el sector agropecuario en cantidad significativa. Más adelante se mostrará con mayor detalle que el sector agropecuario intercambió productos con los otros dos sectores sin que canalizara hacia ellos volúmenes considerables de recursos. Resulta claro, también, que la nueva forma de producción agropecuaria propició el desarrollo del propio sector; además, en vista de que el crecimiento industrial se vinculó casi exclusivamente con el mercado interno, fue necesario que el sector agropecuario exportara productos y servicios y obtuviera divisas en cantidad suficiente para financiar un nivel creciente de importaciones de maquinaria, equipo y materias primas industriales, mientras avanzaba la sustitución de importaciones. El sector agropecuario logró esto a través de un sector dinámico de exportación, aun en presencia de una relación de precios de intercambio descendente y de precios relativos internos 
que se movian en sentido desfavorable. El sector de servicios (turismo) ayudó en el incremento de la capacidad para importar, fenómeno poco común en países subdesarrollados, con lo que alivió la carga del sector agrícola.

Volviendo al efecto redistribución de la reforma agraria mexicana, debe señalarse que, aunque modesta, en algo modificó la estructura del gasto interno. En la actualidad, el sector agropecuario dedica el $55.2 \%$ de su gasto total de consumo a alimentos y bebidas (producidos en gran parte por el mismo sector agrícola); en cambio, el sector industrial destina sólo el $46.6 \%$ y el de servicios únicamente el $39 \%$ de sus gastos a esos bienes. La distinta distribución del gasto corrobora la ley de Engel. Como en 1936-1940 la diferencia del ingreso por persona entre los distintos sectores era ya bastante marcada, la redistribución de ingresos a favor del sector agropecuario determinó un mayor consumo de alimentos y bebidas, ya que el aumento del ingreso de los agricultores se destinó probablemente en mayor medida a adquirir esta clase de bienes. Ocurrió un mayor autoconsumo de los mismos bienes, que se tradujo en menor oferta relativa de alimentos al resto de la economía, en alza de los precios de estos bienes, en cambio de los precios relativos y en transferencias de ingresos del sector industrial y del de servicios al agropecuario. Cabe señalar, en este sentido, que de 1939 a 1945 el precio de los alimentos a nivel del productor aumentó con mayor rapidez que el índice general de precios. Como el sector agropecuario consume menos bienes industriales y servicios que los otros sectores, la redistribución de ingresos influyó para disminuir la cantidad demandada de éstos, creando quizá capacidad productiva no utilizada que permite explicar la elevada elasticidad que la oferta de bienes industriales mostró durante la segunda Guerra Mundial. En esta época, la necesidad de los países industrializados de dedicarse a la producción bélica facilitó el incremento de las exportaciones mexicanas y originó aumentos de los precios que determinaron alzas en el ingreso y en la demanda interna de bienes industriales. Esta última fue surtida, y aun se produjeron excedentes que fueron exportados (principalmente de textiles), pese a que resultaba difícil ampliar o renovar el equipo.

El otro efecto de la reforma agraria, al cual llamamos antes efecto movilidad, tuvo gran significado en el desarrollo del país. Consistió en que el antiguo peón, convertido en empresario agrícola, pudo desde entonces obedecer más libremente a sus impulsos en la selección de cultivos y tratar de completar sus ingresos ofreciendo libremente, en forma temporal o permanente, sus servicios en el mercado de trabajo agrícola, industrial, de servicios o externo. Su primera reacción fue quizá la de mayor arraigo a la tierra y menor movilidad, con la esperanza de que sus ingresos continuaran aumentando. Sin embargo, la productividad de la tierra dedicada a la producción de alimentos no cambió mayormente entre 1936 y 1945, como tampoco la producción de cereales. Esto muestra que si la población campesina se hubiera desplazado en mayor medida a las zonas urbanas, en forma inmediata a la reforma agraria, la producción de alimentos habría descendido y el consumo per capita disminuido. (Este argumento se apoya en la afirmación, hecha antes, de que el producto marginal del 
trabajo en el sector agropecuario era positivo aunque menor que el producto medio.) Transcurridos algunos años, el aumento de la población, el lento avance de la productividad en el sector agropecuario de subsistencia, las obras de comunicación y los gastos de educación influyeron en la movilidad de la mano de obra, que el crecimiento urbano aceleró. Ya para entonces la política de riego había avanzado en buena medida, de manera que los rendimientos agrícolas de la agricultura comercial comenzaron a aumentar al mismo tiempo que se aceleró el desplazamiento de la población rural sin que disminuyera la producción de alimentos y otros productos agrícolas. En las zonas tradicionalmente productoras de cereales las esperanzas de los campesinos no se concretaron en mejoras ulteriores de su ingreso real, las condiciones de producción no cambiaron y la presión demográfica sobre los recursos se vio intensificada por descensos del coeficiente de mortalidad. Las comunicaciones mejoraron lo suficiente en forma de troncales $y$ caminos vecinales y con subsidios al transporte, lo que facilitó el desplazamiento humano y apoyó el efecto que la reforma agraria ejerció sobre la movilidad del trabajo. ${ }^{7}$ El elemento que importa destacar es que para entonces, a pesar del desplazamiento de la mano de obra agrícola, su productividad aumentaba con la velocidad necesaria para asegurar una producción creciente con mayor rapidez que la población, es decir, que se registraron aumentos que permitieron alimentar mejor una mayor población, aunque en términos relativos la población dedicada a la agricultura disminuyó. De hecho, cuando las comunicaciones facilitaron el traslado ocupacional a los servicios y a la industria, se presentó una oferta ilimitada de mano de obra, a una tasa de retribución igual al nivel de subsistencia, más un premio suficiente para estimular el desplazamiento, que inclusive facilitó el rezago de los salarios respecto a precios y condujo a un alza de utilidades durante el proceso inflacionario de los años cuarenta, sin presiones sindicales dignas de consideración.

Cuando en la década de los cuarenta se presentó el auge de la demanda externa, la movilidad de los factores antes señalada influyó en la diversificación de los cultivos y cobró importancia el cultivo de productos de exportación tales como el algodón y el café. Asimismo, las condiciones políticas imperantes afianzaron la política gubernamental de desarrollo, que se expresó en inversiones en obras hidráulicas, educación, comunicaciones y transportes, energía, etc., las cuales se tradujeron en mayor productividad de la tierra y de la mano de obra $y$, especialmente, en ampliación del mercado interno para el que producía la industria, que fue además estimulada por el proceso de sustitución de importaciones.

La expropiación petrolera. La expropiación petrolera fue otro cambio institucional que se considera como uno de los principales antecedentes del proceso de desarrollo económico del país. Como en una

7 El movimiento del campo a la ciudad motivó desplazamientos regionales importantes. Aceleraron su crecimiento el Distrito Federal y los estados fronterizos: Tamaulipas, Baja California Norte, Nuevo León, y perdieron población en el movimiento migratorio los estados del centro y del sur: México, Michoacán, Hidalgo, Tlaxcala, Oaxaca, Guerrero y Chiapas. 
sección posterior de este trabajo se trata el proceso de sustitución de importaciones en su conjunto, proceso también seguido por la industria petrolera, baste señalar aquí que esa medida significó una notable alteración en el proceso de decisiones de inversión y de política de desarrollo de la industria, toda vez que de orientada al mercado de exportación y sujeta a las condiciones del mercado mundial y a dećisiones tomadas en el exterior pasó a vincularse con el mercado interno y a dirigirse de acuerdo con el comportamiento a largo plazo de la economía nacional; es decir, para fines analíticos, su inversión se convierte en autónoma.

Más adelante se tratará de fundamentar la aseveración de que la economia mexicana ha ganado resistencia en cuanto a la influencia externa, habiendo disminuido asimismo la que ejercen las fluctuaciones de la balanza de pagos.

La expropiación petrolera ayudó a este proceso, así que el sistema pasó de consistir en un simple receptor de choques exógenos a convertirse gradualmente en generador de sus propias oscilaciones cíclicas. En resumen, se trata de un interesante caso de estudio del comportamiento conjunto del desarrollo económico y las oscilaciones cíclicas, en que las causas del ciclo que en un principio se recibían del exterior pasan a ser más y más, como producto del desarrollo, generadas internamente. El que una economía se independice - relativamente- del exterior no quiere decir que necesariamente se torne más estable su nivel del ingreso. Pero para llegar a conocer en toda su amplitud y significado este hecho tan importante en sí mismo es necesario ordenar la información existente pero dispersa, reconstruir las series económicas básicas disponibles, hasta 1925 cuando menos, y analizarlas.

\section{TRANSFERENCIAS INTERSECTORIALES DE RECURSOS}

La distribución del ingreso por sectores indica la aportación de éstos a la producción de bienes de uso final y su capacidad para realizar gastos con recursos propios, capacidad que, para un sector individual, se puede complementar con transferencias provenientes de otros sectores. Un sector puede gastar menos de lo que produce e invertir en activos financieros o gastar más de lo que produce y recibir recursos de otros sectores al emitir y colocar deuda. El mecanismo fiscal produce también transferencias de ingresos, puesto que es muy raro que el sector gubernamental gaste en cada sector lo mismo que les extrae en forma de impuestos y colocaciones de deuda. Las transferencias intersectoriales de recursos son importantes en tanto que permiten conocer las diferencias en los ahorros e inversiones por sectores así como algunos de los mecanismos que explican la diversidad de tasas de crecimiento de la formación de capital de los distintos sectores y las modificaciones de la estructura productiva de un país. En México, el mecanismo financiero ha operado canalizando hacia el sector industrial recursos del agropecuario y del de servicios. (Véase el cuadro 5.) Aproximadamente tres quintas partes del ahorro financiero realizado en el sector agropecuario regresa en forma de créditos al mismo sector, mientras el remanente del ahorro de dicho sector se canaliza al resto 


\section{Cuadro 5}

MÉXICO: Recursos CAPTADOS Y CANALIZADOS POR EL SISTEMA baNCARIO, POR SECTORES DE ACTIVIDAD, 1942-1962

(Millones de pesos de 1960)

\begin{tabular}{|c|c|c|c|c|c|c|c|c|}
\hline \multirow[b]{2}{*}{ Ax̃os } & \multicolumn{3}{|c|}{ Recursos captatios } & \multicolumn{5}{|c|}{ Recursos canalizados } \\
\hline & $\begin{array}{l}\text { Agrope- } \\
\text { cuarto }\end{array}$ & $\begin{array}{l}\text { Indus- } \\
\text { trial }\end{array}$ & Servicios & Total & $\begin{array}{l}\text { Agrope- } \\
\text { cuarlo }\end{array}$ & $\begin{array}{l}\text { Indus- } \\
\text { trial }\end{array}$ & Servicios & Total \\
\hline 942 & 3533.6 & 5048.1 & & 15775.2 & 2106.7 & 3274.5 & & 13332.5 \\
\hline 943 & 994.0 & 6084.4 & & 663.7 & 2133.6 & 3819.2 & 7999.6 & 13 \\
\hline 1944 & 3954.1 & 6291.4 & 9232.6 & $19478 . ?$ & 2495.2 & 4839.7 & & 145 \\
\hline 1945 & 3861.3 & 7096.6 & 9914.2 & 20.872 .1 & 1729.3 & 5821.2 & 764 & 15 \\
\hline 1946 & 3490.3 & 6028.6 & 9145.6 & 18664.5 & 1454.6 & 6330.3 & 74 & 15191.8 \\
\hline 47 & 3631.3 & 5884.7 & 9106.3 & 8622.3 & 1625.1 & 7287.8 & 7719.6 & 16632.5 \\
\hline 48 & 4230.9 & 6681.4 & 10032.7 & +5.0 & 1696.3 & 8097.8 &. .1 & 18916.2 \\
\hline 49 & 4815.0 & 7257.5 & 111 & & 1873.3 & 845 & & 20 \\
\hline & 5417.8 & 8100.7 & 12528.8 & & 2003.2 & 897 & 107 & \\
\hline 951 & 5346.6 & 8255.7 & 12606.3 & 26208.6 & 2032.3 & 10388.4 & 33.8 & 54.5 \\
\hline 952 & 5206.0 & 8703.9 & 13205.2 & 27125.1 & 2367.1 & 10937.5 & 995 & 54.6 \\
\hline 953 & 5753.2 & 9518.6 & 14850.0 & 30121.8 & 3134.0 & 12390.5 & 11518.5 & 27043.0 \\
\hline 954 & 6939.8 & 10650.1 & 16765.4 & 34355.3 & 2966.4 & 14052.7 & 127 & 29766.9 \\
\hline 955 & 7362.4 & 11388.2 & 17517.4 & 36268.0 & 3505.5 & 12886.0 & 12405.3 & 28796.8 \\
\hline 956 & 7220.1 & 12683.8 & 19123.4 & 39027.3 & 3805.0 & 13882.5 & 13108.7 & 30796.2 \\
\hline 957 & 7626.2 & 13325.3 & 20049.5 & 1.0 & 4039.1 & 15493.0 & 13990.5 & 33522.6 \\
\hline 158 & 8297.7 & 15015.0 & 20590.7 & & 4413.6 & 17169.6 & 15794.6 & 37377.8 \\
\hline 1959 & 8556.5 & 16247.7 & 23265.9 & & 5256.4 & 18987 & 16649.1 & 40892.5 \\
\hline 960 & 9059.1 & 17751.7 & 25554.1 & 52364.9 & 5801.4 & 21052.9 & 19559.8 & 46414.1 \\
\hline & 9815.6 & 19345.8 & 27905.9 & & 6512.5 & 23470.8 & 21711.9 & 51695.2 \\
\hline 1962 & 10797.6 & 21281.3 & 30697.8 & 62776.7 & 7022.2 & 28357.3 & 21930.1 & 57309.6 \\
\hline
\end{tabular}

Fuente: Banco de México, Informes anuales.

de la economia; el sector industrial recibe una proporción similar en exceso de lo que ahorra en el sistema financiero. ${ }^{8}$

En cambio, el sistema fiscal reasigna fondos de manera diferente. La transferencia intersectorial de ingresos producida por el mecanismo fiscal no es importante para el sector agropecuario. Sólo en períodos postdevaluatorios de corta duración (1950-1952, 1955-1956) las elevaciones de las tasas de los impuestos ad valorem a la exportación gravaron a los productos agropecuarios en grado suficiente como para extraerles recursos y canalizarlos al resto de la economía. (Véase el cuadro 6.) Durante la mayor parte del periodo considerado, el sector agropecuario pagó impuestos que fluctuaron entre el 40 y el $80 \%$ de los gastos

8 En la estimación se supuso que los recursos captados por el sistema financiero corresponden a ahorro de los sectores proporcional a su participación en el producto bruto interno. 


\section{Cuadro 6}

MÉXICO : INGRESOS Y GASTOS GUBERNAMENTALES, POR SECTORES DE ACTIVIDAD, 1877-78 A $1910-11$

(En miles de pesos a precios corrientes)

\begin{tabular}{|c|c|c|c|c|c|c|}
\hline \multirow[b]{2}{*}{ Años } & \multicolumn{4}{|c|}{ Impuestos } & \multirow{2}{*}{$\frac{\text { Gastos }}{\text { Servicios }}$} & \multirow[b]{2}{*}{$(4) /(5)$} \\
\hline & Totales & $\begin{array}{l}\text { Agrope- } \\
\text { cuarto }\end{array}$ & $\begin{array}{l}\text { Indus- } \\
\text { trial }\end{array}$ & Servicios & & \\
\hline & (1) & (2) & (3) & (4) & (5) & \\
\hline $1877-78$ & 20089 & 8247 & 5045 & 6797 & 19420 & .35 \\
\hline $1878-79$ & 18064 & 5685 & 4073 & 8306 & 18474 & .45 \\
\hline $1879-80$ & 21371 & 6970 & 5523 & 8878 & 20433 & .43 \\
\hline $1880-81$ & 24895 & 8173 & 5297 & 11425 & 24087 & .47 \\
\hline $1881-82$ & 30466 & 10119 & 5917 & 14430 & 26247 & .55 \\
\hline $1882-83$ & 32258 & 10942 & 6112 & 15204 & 33974 & .45 \\
\hline $1883-84$ & 32698 & 10366 & 5590 & 16742 & 28180 & .59 \\
\hline $1884-85$ & 30192 & 9147 & 4760 & 16285 & 35918 & .45 \\
\hline $1885-86$ & 27785 & 8840 & 4640 & 14305 & 26164 & .55 \\
\hline $1886-87$ & 31158 & 10262 & 5367 & 15529 & 31162 & .49 \\
\hline $1887-88$ & 34009 & 11262 & 5752 & 16995 & 34675 & .49 \\
\hline $1888-89$ & 34375 & 11291 & 5766 & 17318 & 34749 & .50 \\
\hline $1889-90$ & 38587 & 13141 & 6998 & 18448 & 34912 & .53 \\
\hline $1890-91$ & 37392 & 12203 & 6244 & 18945 & 39086 & .48 \\
\hline 1891-92 & 37475 & 12119 & 6208 & 19148 & 40678 & .47 \\
\hline $1892-93$ & 37692 & 10197 & 5878 & 21617 & 43684 & .50 \\
\hline $1893-94$ & 40212 & 10223 & 7294 & 22695 & 41922 & .54 \\
\hline $1894-95$ & 43946 & 11975 & 9124 & 22847 & 42905 & .53 \\
\hline $1895-96$ & 50521 & 16030 & 12773 & 21718 & 45103 & .48 \\
\hline $1896-97$ & 51496 & 16678 & 14397 & 20421 & 48365 & .42 \\
\hline $1897-98$ & 52698 & 16340 & 14970 & 21388 & 51815 & .41 \\
\hline $1898-99$ & 60139 & 19998 & 16947 & 23194 & 53500 & .43 \\
\hline $1899-00$ & 62261 & 19195 & 19218 & 25848 & 57945 & .45 \\
\hline $1900-01$ & 62999 & 17781 & 18672 & 26546 & 59423 & .45 \\
\hline $1901-02$ & 66147 & 17294 & 20507 & 28346 & 63081 & .45 \\
\hline $1902-03$ & 76023 & 20627 & 23581 & 31815 & 68222 & .47 \\
\hline $1903-04$ & 86474 & 20999 & 26819 & 38656 & 76382 & .51 \\
\hline $1904-05$ & 92084 & 22673 & 28712 & 40699 & 79152 & .51 \\
\hline $1905-06$ & 101973 & 27464 & 27887 & 46622 & 79470 & .59 \\
\hline 1906-07 & 114286 & 30508 & 30688 & 53.090 & 85176 & .62 \\
\hline $1907-08$ & 111811 & 31387 & 30512 & 49812 & 93197 & .53 \\
\hline $1908-09$ & 98776 & 22367 & 24678 & 51731 & 92967 & .56 \\
\hline $1909-10$ & 106328 & 29326 & 29107 & 47895 & 95038 & .50 \\
\hline $1910-11$ & 111142 & 27364 & 30069 & 53709 & 100914 & .53 \\
\hline
\end{tabular}

Fuentes: Estadisticas económicas del Porfiriato. Fuerza de trabajo y actividad ecanómica por sectores, El Colegio de México, 1964; México. Cincuenta años de Revolución, I. La economía, Fondo de Cultura Económica, 1961.

gubernamentales realizados en el fomento de ese sector, y las diferencias no tienen mucha significación en el total transferible. Esto prueba que, desde el punto de vista adoptado en esta sección, la afirmación que con frecuencia se hace de que el sector agropecuario ha sostenido el desarrollo del resto de la economia no es válida, toda vez que ha obtenido ingresos en forma neta, pues lo recibido mediante el mecanismo fiscal es mayor que lo transferido por conducto del 
sistema financiero. Dicho sea de paso, el papel de este sector ha sido muy importante como productor de alimentos, materias primas y productos con cuyas ventas se obtienen divisas. Esta afirmación adquiere mayor precisión cuando se observa el movimiento de los precios relativos internos, que se modificaron en contra del sector agropecuario. Específicamente, los precios agrícolas descendieron en relación con los precios industriales y los servicios. Considerando a $1950=100$, en 1960 los precios de los productos agropecuarios habían descendido a 81.5 respecto de los servicios, y a 83.2 en relación con las mercancías de la industria manufacturera. A su vez, en el mismo período, los precios de los productos industriales descendieron a 87.6 respecto de los servicios; así que el movimiento de los precios relativos actuó de manera acentuada en contra de la agricultura y a favor de los servicios. El deterioro relativo de los precios de los productos agrícolas refleja probablemente las condiciones imperantes en el mercado internacional de los mismos en esos años y, acaso también, la estructura de su mercado, ya que mientras la industria y los servicios se enfrentan a una oferta de mano de obra organizada, que impide que las tasas de salarios nominales se reduzcan, la mano de obra ocupada en la agricultura no cuenta con esa defensa. Asimismo, aunque los precios de los productos industriales estén vinculados al mercado internacionál por las importaciones, el grado de protección arancelaria otorgado a la industria permite movimientos de precios internos independientes de las cotizaciones del mercado mundial, aun para los bienes de capital, en tanto que muchos precios agrícolas se rigen internamente por las condiciones del mercado internacional de materias primas en el que compiten con exportaciones.

Los sectores industrial y de servicios han operado en forma opuesta el uno al otro. Por medio del mecanismo fiscal se redistribuyen ingresos al sector de servicios y a través del sistema financiero se canalizan a la industria. Durante el Porfiriato se captaban impuestos de todos los sectores y sólo se hacían transferencias al de servicios (Véase el cuadro 6.) En la época reciente, los sectores industriales y de servicios coinciden en el pago de impuestos (en monto, tendencia y fluctuaciones), y aunque los gastos gubernamentales en servicios son mayores, también se efectúan erogaciones importantes en obras de promoción del sector industrial. ${ }^{9}$ El hecho es que mientras la recaudación fiscal de ambos sectores coincide en nivel, los pagos directos al sector de servicios superan más de cuatro veces las erogaciones gubernamentales realizadas en bienes industriales o en inversiones y otros gastos de fomento industrial. (Véase el cuadro 7.)

Mientras los pagos de impuestos de los dos sectores son similares, los gastos de promoción constituyen únicamente las tres quintas partes de los impuestos pagados por el sector; en cambio, los gastos totales en el sector de servicios son como mínimo dos y media veces los

9 Los impuestos pagados por el sector de servicios no son conceptos totalmente comparables con los gastos hechos por el gobierno en este sector, sobre todo por el pago de servicios personales, que eleva mucho las erogaciones en el mismo. Para conocer con exactitud el efecto redistribución de la política fiscal sería menester examinar las corrientes de fondos entre los subgrupos del sector de servicios, pero esto tomaría más tiempo del que se ha podido dedicar a este asunto 


\section{Cuadro 7}

México: INGResos Y gastos gubernamentales, POR SECTORES DE ACTIVIDAD, 1940 A 1962 (A precios de 1960)

\begin{tabular}{|c|c|c|c|c|c|c|c|c|c|c|c|c|c|}
\hline & \multicolumn{4}{|c|}{ Impuestos } & \multirow{2}{*}{$\begin{array}{l}\text { Otros } \\
\text { ingre- } \\
\text { sos }\end{array}$} & \multicolumn{4}{|c|}{ Gestos } & \multirow[b]{2}{*}{ Otros } & \multirow[b]{2}{*}{$\frac{(2)}{(7)}$} & \multirow[b]{2}{*}{$\frac{(3)}{(8)}$} & \multirow[b]{2}{*}{$\frac{(4)}{(9)}$} \\
\hline & Totales & $\begin{array}{l}\text { Agrope- } \\
\text { cuario }\end{array}$ & $\begin{array}{l}\text { Indus- } \\
\text { trial }\end{array}$ & $\begin{array}{c}\text { Servi- } \\
\text { cios }\end{array}$ & & Toteles & $\begin{array}{l}\text { Agrope- } \\
\text { cuario }\end{array}$ & $\begin{array}{l}\text { Indus- } \\
\text { trial } \\
\end{array}$ & $\begin{array}{c}\text { Servi- } \\
\text { cios }\end{array}$ & & & & \\
\hline & (1) & (2) & (3) & (4) & (5) & (6) & (7) & (8) & (9) & (10) & (11) & (12) & (13) \\
\hline $\begin{array}{l}1940 \\
1941 \\
1942 \\
1943 \\
1944 \\
1945 \\
1946 \\
1947 \\
1948 \\
1949 \\
1950 \\
1951 \\
1952 \\
1953 \\
1954 \\
1955 \\
1956 \\
1957 \\
1958 \\
1959 \\
1960 \\
1961 \\
1962\end{array}$ & $\begin{array}{ll}2 & 351.2 \\
2 & 331.0 \\
2 & 457.5 \\
2 & 955.2 \\
3 & 010.3 \\
2 & 864.4 \\
3 & 187.9 \\
3 & 357.1 \\
3 & 360.9 \\
4 & 567.4 \\
4 & 767.1 \\
5 & 922.2 \\
6 & 254.5 \\
5 & 409.8 \\
5 & 993.6 \\
7 & 667.8 \\
7 & 940.9 \\
7 & 476.6 \\
7 & 825.9 \\
8 & 477.1 \\
9 & 301.2 \\
9 & 835.7\end{array}$ & $\begin{array}{ll} & 321.2 \\
329.9 \\
379.2 \\
416.2 \\
340.2 \\
319.8 \\
305.1 \\
294.0 \\
305.5 \\
& 861.7 \\
& 834.8 \\
1 & 025.0 \\
& 967.4 \\
& 824.6 \\
1 & 181.3 \\
1 & 581.8 \\
1 & 344.7 \\
1 & 071.4 \\
1 & 053.6 \\
1 & 035.8 \\
1 & 003.9 \\
& 964.1\end{array}$ & $\begin{array}{ll} & 959.0 \\
& 974.0 \\
1 & 045.4 \\
1 & 278.6 \\
1 & 304.2 \\
1 & 234.9 \\
1 & 329.8 \\
1 & 375.9 \\
1 & 356.7 \\
1 & 769.4 \\
1 & 961.3 \\
2 & 373.3 \\
2 & 634.1 \\
2 & 349.5 \\
2 & 448.1 \\
3 & 183.9 \\
3 & 512.0 \\
3 & 404.3 \\
3 & 408.1 \\
3 & 915.5 \\
4 & 257.1 \\
4 & 488.2\end{array}$ & $\begin{array}{ll}1 & 070.4 \\
1 & 027.1 \\
1 & 032.9 \\
1 & 260.4 \\
1 & 365.9 \\
1 & 309.7 \\
1 & 553.0 \\
1 & 687.2 \\
1 & 698.7 \\
1 & 936.3 \\
1 & 971.0 \\
2 & 523.9 \\
2 & 653.0 \\
2 & 235.7 \\
2 & 364.2 \\
2 & 902.1 \\
3 & 084.2 \\
3 & 000.9 \\
3 & 364.2 \\
3 & 525.8 \\
4 & 040.2 \\
4 & 383.4\end{array}$ & 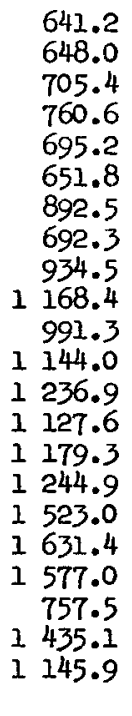 & $\begin{array}{rr}3 & 188.3 \\
3 & 329.4 \\
3 & 744.2 \\
3 & 771.5 \\
3 & 561.5 \\
3 & 910.6 \\
3 & 469.2 \\
4 & 074.9 \\
4 & 790.6 \\
5 & 248.7 \\
5 & 273.3 \\
6 & 011.7 \\
7 & 843.1 \\
7 & 116.1 \\
8 & 130.8 \\
8 & 229.9 \\
9 & 107.7 \\
9 & 629.2 \\
10 & 354.1 \\
10 & 417.2 \\
11 & 794.9 \\
12 & 791.0 \\
13 & 479.8\end{array}$ & $\begin{array}{ll} & 412.5 \\
525.2 \\
620.3 \\
566.4 \\
620.9 \\
705.1 \\
556.7 \\
711.7 \\
641.1 \\
779.3 \\
659.2 \\
745.9 \\
11300.7 \\
1095.2 \\
1 & 392.5 \\
1 & 235.0 \\
1 & 161.9 \\
1 & 230.2 \\
1 & 252.8 \\
1 & 216.0 \\
1 & 278.6 \\
1 & 317.5 \\
1 & 462.6\end{array}$ & 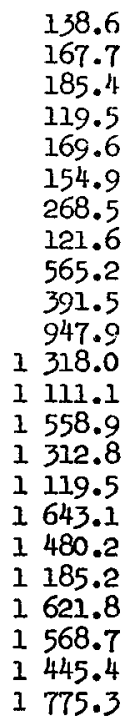 & $\begin{array}{ll}1 & 942.2 \\
2 & 182.3 \\
2 & 480.6 \\
2 & 620.1 \\
2 & 259.3 \\
2 & 228.0 \\
2 & 147.3 \\
2 & 405.9 \\
2 & 709.3 \\
3 & 292.0 \\
2 & 962.7 \\
3 & 007.1 \\
4 & 033.0 \\
3 & 674.8 \\
4 & 222.5 \\
4 & 456.8 \\
4 & 452.7 \\
5 & 298.0 \\
6 & 087.7 \\
6 & 007.4 \\
6 & 876.4 \\
7 & 508.3 \\
7 & 854.5\end{array}$ & $\begin{array}{ll} & 695.0 \\
454.2 \\
457.9 \\
465.5 \\
511.7 \\
822.6 \\
496.7 \\
835.7 \\
875.0 \\
785.9 \\
703.5 \\
140.7 \\
1398.3 \\
1787.2 \\
1 & 203.0 \\
1 & 418.6 \\
1 & 850.0 \\
1 & 620.8 \\
1 & 828.4 \\
1 & 572.0 \\
2 & 071.2 \\
2 & 519.8 \\
2 & 387.4\end{array}$ & $\begin{array}{l}.78 \\
.63 \\
.61 \\
.73 \\
.55 \\
.45 \\
.55 \\
.41 \\
.48 \\
1.11 \\
1.27 \\
1.37 \\
.74 \\
.75 \\
.85 \\
1.28 \\
1.16 \\
.87 \\
.84 \\
.85 \\
.79 \\
.73\end{array}$ & $\begin{array}{r}6.91 \\
5.81 \\
5.64 \\
10.69 \\
7.69 \\
7.97 \\
4.95 \\
11.32 \\
2.40 \\
4.52 \\
2.07 \\
1.80 \\
2.37 \\
1.51 \\
1.86 \\
2.84 \\
2.14 \\
2.30 \\
2.88 \\
2.41 \\
2.71 \\
3.11\end{array}$ & $\begin{array}{l}.55 \\
.47 \\
.42 \\
.48 \\
.60 \\
.59 \\
.72 \\
.70 \\
.63 \\
.59 \\
.67 \\
.84 \\
.66 \\
.61 \\
.56 \\
.65 \\
.69 \\
.57 \\
.55 \\
.59 \\
.59 \\
.58\end{array}$ \\
\hline
\end{tabular}

Fuente: Secretaría de Hacienda y Crédito Público, Cuenta de la Hacienda Pública. 
impuestos con que se grava al mismo. En 1940 el sistema fiscal captaba del sector agropecuario el $15 \%$ de los impuestos totales, cantidad que en 1961 descendió a menos del $10 \%$. De manera que fueron los sectores industrial y de servicios los que aportaron el grueso de los fondos fiscales ( $y$ ahorros) necesarios para financiar el crecimiento económico del país.

La operación del sistema financiero compensó sólo en parte la influencia del mecanismo fiscal. Esto no fue resultado de operaciones del mercado sino de la política de control selectivo de crédito del banco central y de la política crediticia de las instituciones nacionales de crédito, que lograron canalizar a la industria más recursos prestables que los ahorros financieros producidos por ésta. Dichos recursos provenían del sector de servicios y del agropecuario.

\section{LOS FACTORES DE LA PRODUCCIÓN}

Es éste un campo en el que poco puede decirse con certeza. Falta aún que se realice el primer intento global de estimar una función produción para la economía mexicana. No es posible indicar la forma en que los factores productivos se han combinado en su contribución al desarrollo económico del país. Las limitaciones son muy serias: no existe una serie anual de capital tangible totalmente satisfactoria, o para un período bastante largo, ni se conoce la mano de obra efectivamente ocupada y la desocupada. Tampoco existe información reciente de la distribución del ingreso por pagos a los factores. De manera que no es posible determinar cuantitativamente el valor agregado por cada factor productivo, o formarse una idea acerca de la productividad de los factores y de la forma en que contribuyeron al desarrollo económico sostenido. Sin embargo, el crecimiento es en parte un proceso complejo de dinámica demográfica que conviene investigar para examinar hipótesis sobre distintas medidas de política económica y distinguir los niveles convenientes de gastos en educación. En un sentido general, el comportamiento de algunas variables demográficas influye en forma muy determinante en el proceso de desarrollo económico. Así, el crecimiento de la población modifica la fuerza de trabajo, el valor agregado, amplía el número de consumidores y las necesidades de educación; a su vez, la transferencia de población rural a urbana modifica las condiciones de la oferta de trabajo, la estructura de la demanda de los consumidores y la de servicios públicos.

La población, según los censos, aumentó de 16.6 millones en 1930 , sólo $9 \%$ mayor que la de fines del Porfiriato, a 34.9 millones en 1960. El abatimiento de la mortalidad ha resultado en sucesivos incrementos de la tasa de crecimiento de la población; dicha tasa, que fue de $1.1 \%$ anual en el primer decenio de este siglo, ascendió a $3.5 \%$ en la presente década. La población en ciudades mayores de 10000 habitantes significaba el $12.6 \%$ del total en 1900 y aumentó a $35.4 \%$ en 1960. No cabe duda que la urbanización ha acompañado al crecimiento económico del país; según una encuesta reciente, el ingreso por persona aumenta directamente con el tamaño de la población. ${ }^{10}$

10 En poblaciones de menos de 2500 habitantes el ingreso medio por persona es de 125.6 pesos mensuales; en las de 2500 a 10000 , de 182.8 pesos; en las de 
Los gastos en educación han modificado cualitativamente a la población, mejorando su preparación técnica para desempeñar actividades económicas. La educación eleva la productividad marginal del trabajo, facilita la absorción de avances tecnológicos, evita desajustes sectoriales y permite gozar de una vida más plena. El cuadro 8 muestra parte del avance educativo. El esfuerzo educativo ha modificado la

\section{Cuadro 8}

Méxioo: INDICADORes de La edUCActón

(Cifras en miles)

\begin{tabular}{lrrrrr}
\hline \multicolumn{1}{c}{ Concepto } & 1910 & 1930 & 1940 & 1950 & 1960 \\
\hline Población total & 15160 & 16552 & 19655 & 25791 & 34923 \\
Mayores de 6 años & & 13542 & 16221 & 21039 & 27988 \\
Analfabetos & & 9017 & 9449 & 8942 & 10573 \\
Alfabetos & 4525 & 6770 & 11766 & 17414 \\
Porciento de la población esco- & & & & \\
$\quad$ lar inscrita en escuela: & & & & \\
Primaria (6-14) & 34.3 & 45.1 & 57.2 & 55.9 \\
Media (15-19) & 3.4 & 6.0 & & 12.7 \\
Superior (20-24) & & & 1.3 & 2.7 \\
\hline
\end{tabular}

Fuente: Censos de población.

naturaleza de la fuerza de trabajo. Por ejemplo, los alfabetizados formaban un tercio de la población mayor de 6 años en 1930 y constituían el $62 \%$ en 1960 . El crecimiento de la población con educación media y superior ha sido también rápido, $\mathrm{y}$ la importancia relativa de las tradicionales ocupaciones liberales ha tendido a disminuir mientras la de las técnicas, como la ingeniería, ha aumentado.

$\mathrm{La}$ estructura ocupacional no se ha modificado mayormente como resultado del proceso de desarrollo (véase el cuadro 9), lo que muestra el enorme esfuerzo que falta por realizar para que una parte creciente de la fuerza de trabajo sea absorbida por la economía de mercado en labores de alta productividad, frente al incremento del crecimiento demográfico.

En 1960, la población ocupada en la agricultura constituía un porciento similar al de principios de siglo. El ún,co cambio estructural noiable fue el crecimiento de la rano de obra industrial de 1940 a 1960 , que, al ascender a una tasa de $5.4 \%$ anual, acusó un aumento más rápido que el de la fuerza de trabajo total $(3.3 \%)$ y más del doble que el incremento de la fuerza de trabajo ocupada en el sector agropecuario $(2.3 \%)$.

Parece ser que se han presentado faltantes sensibles sólo en la oferta de técnicos de nivel medio, y deben haber sido aminorados con profesionistas con preparación deficiente y con personal de preparación

10000 a 150000 , de 252.1 pesos; en las de 150000 a 500000 , de 328.4 pesos; en las de más de 500000 , de 484.3 pesos; y en el Distrito Federal, de 545.8 pesos mensuales. Banco de México, Oficina de Estudios de Proyecciones Agrícolas, Encuesta sobre ingresos y gastos familiares, 1963; próxima a publicarse. 


\section{Cuadro 9}

México: Estructura de la fuerza de trabajo

(Porcientos del total)

\begin{tabular}{lcccc}
\hline & & \multicolumn{3}{c}{ Ocupada en actividades } \\
\cline { 3 - 5 } Año & Población total & Agropecuarias & Industriales & Servicios \\
\hline 1900 & 100.0 & 56.2 & 14.4 & 29.5 \\
1910 & 100.0 & 60.9 & 13.8 & 25.3 \\
1940 & 100.0 & 65.4 & 12.7 & 21.9 \\
1950 & 100.0 & 58.3 & 15.9 & 25.7 \\
1960 & 100.0 & 54.1 & 19.0 & 26.9 \\
\hline
\end{tabular}

Fuentes: Estadisticas económicas del Porfiriato. Fuerza de trabajo y actividad económica por sectores, El Colegio de México, 1964; y censos de población.

inferior a la requerida en estas ocupaciones, que han recibido entrenamiento directamente en los empleos y ascendido en la escala ocupacional.

Estimaciones recientes de la inversión bruta fija, en un sentido amplio que incorpora algunos gastos de mantenimiento, indican que el coeficiente de inversión en el producto ha venido ascendiendo a razón del $10 \%$ anual en los años cincuenta y alcanzaba más de un quinto del producto bruto en 1960. Las asignaciones para consumo de capital fijo significan un tercio, aproximadamente, de la inversión bruta fija. A su vez, la relación capital-producto ha tendido a decrecer de 3 , aunque recientemente casi coinciden la relación marginal y la media, lo que significa su estabilizaciói global. El contenido de importaciones de la inversión, aunque en forma errática, ha tendido a disminuir hacia un valor próximo a un quinto del total. Asimismo, se aprecia que la inversión privada significa dos tercios de la global, y como la inversión pública ha utilizado ahorros en forma creciente, son patentes el nivel y el dinamismo del ahorro privado, cuya elasticidad-ingreso es ligeramente mayor que la unidad, hecho que resulta congruente con la deficiente distribución del ingreso nacional.

\section{LA DEMANDA gLOBAL Y SUS COMPONENTES}

El componente más importante de la demanda global es el consumo. Sin embargo, poco se sabe acerca de su comportamiento y estructura. Las cifras globales disponibles incluyen el cambio de los inventarios. Esto probablemente estabiliza a corto plazo los cambios de ambas variables, puesto que es de esperar que en períodos cortos los movimientos sean opuestos en dirección aunque su tendencia secular coincida. La falta de una serie estadística sobre inventarios impide un análisis correcto del consumo y de la inversión. La suma de ambos muestra que aproximadamente tres cuartas partes de la demanda global están compuestas por estas variables.

Es conveniente considerar, aunque sea brevemente, cuál es la estructura del consumo para saber qué influencia tiene y cómo se modi- 
fica a largo plazo. Una encuesta reciente ${ }^{11}$ permite identificar las características más importantes del consumo, su composición y elasticidades-ingreso y, con base en éstas, deducir su evolución cronológica.

El consumo. El total de gasto de las familias se distribuye, por sectores, como sigue : agropecuario, $30 \%$; industrial, $23 \%$; y servicios,

Cuadro 10

MÉXico: Estructura del gasto fN CONSUMo, 1963 (Porcientos del total)

\begin{tabular}{|c|c|c|c|c|c|c|c|c|}
\hline $\begin{array}{l}\text { Bstratos de } \\
\text { Ingresc }\end{array}$ & $\begin{array}{l}\text { Porcien } \\
\text { to del } \\
\text { numero } \\
\text { de fa- } \\
\text { milias }\end{array}$ & $\begin{array}{l}\text { Total } \\
\text { de } \\
\text { gesto }\end{array}$ & $\begin{array}{c}\text { Alimen } \\
\text { tos, } \\
\text { bebidas } \\
\text { y tebe- } \\
\text { co }\end{array}$ & $\begin{array}{l}\text { Ropa } \\
\text { y cal } \\
\text { zado }\end{array}$ & $\begin{array}{c}\text { Alumbra } \\
\text { do, ha- } \\
\text { bita- } \\
\text { ción y } \\
\text { otros } \\
\text { servi- } \\
\text { cios }\end{array}$ & $\begin{array}{l}\text { Vehículos, } \\
\text { muebles y } \\
\text { eparatos } \\
\text { domésti- } \\
\text { cos }\end{array}$ & $\begin{array}{l}\text { Segh- } \\
\text { ros, } \\
\text { pago } \\
\text { de hI } \\
\text { pote- } \\
\text { ca y } \\
\text { ahorro }\end{array}$ & $\begin{array}{l}\text { Otros } \\
\text { gastos }\end{array}$ \\
\hline \multicolumn{9}{|c|}{ Agricultura } \\
\hline $\begin{array}{r}0-300 \\
301 \text { - } 600 \\
601-1000 \\
1001-1500 \\
1501 \text { - } 3000 \\
3001-4500 \\
4501-6000 \\
6001 \text { - } 10000 \\
\text { Más de } 10000\end{array}$ & $\begin{array}{r}12.34 \\
14.92 \\
7.55 \\
2.14 \\
4.07 \\
0.91 \\
0.39 \\
0.32 \\
0.07\end{array}$ & $\begin{array}{l}4.76 \\
7.10 \\
4.97 \\
2.09 \\
6.40 \\
2.25 \\
1.28 \\
0.95 \\
0.20\end{array}$ & $\begin{array}{l}6.64 \\
9.82 \\
6.65 \\
2.62 \\
7.06 \\
2.02 \\
0.77 \\
0.58 \\
0.15\end{array}$ & $\begin{array}{l}5.1 .4 \\
7.15 \\
5.08 \\
1.99 \\
6.68 \\
1.66 \\
1.15 \\
0.83 \\
0.20\end{array}$ & $\begin{array}{l}3.58 \\
4.82 \\
3.53 \\
1.48 \\
4.27 \\
1.36 \\
0.66 \\
0.68 \\
0.08\end{array}$ & $\begin{array}{l}1.15 \\
1.96 \\
1.70 \\
0.76 \\
7.85 \\
4.63 \\
5.74 \\
5.87 \\
0.98\end{array}$ & $\begin{array}{l}0.09 \\
1.04 \\
4.15 \\
0.49 \\
1.45 \\
5.22 \\
2.55 \\
0.91 \\
-\end{array}$ & $\begin{array}{l}2.47 \\
4.47 \\
3.13 \\
1.96 \\
6.52 \\
2.83 \\
1.63 \\
0.76 \\
0.22\end{array}$ \\
\hline Suma & 42.71 & 30.00 & 36.31 & 29.88 & 20.46 & 30.62 & 15.90 & 23.99 \\
\hline \multicolumn{9}{|c|}{ Industria } \\
\hline $\begin{array}{r}0-300 \\
301-600 \\
601=1000 \\
1001=1500 \\
1501=3000 \\
3001=4500 \\
4501 \text { - } 6000 \\
6001=10000 \\
\text { Más de } 10000\end{array}$ & $\begin{array}{l}1.52 \\
4.26 \\
5.82 \\
3.88 \\
3.14 \\
1.20 \\
0.48 \\
0.18 \\
0.34\end{array}$ & $\begin{array}{l}0.42 \\
2.11 \\
4.27 \\
4.30 \\
4.53 \\
3.46 \\
1.38 \\
0.72 \\
1.84\end{array}$ & $\begin{array}{l}0.61 \\
2.86 \\
5.23 \\
5.19 \\
4.48 \\
2.83 \\
1.10 \\
0.41 \\
0.84\end{array}$ & $\begin{array}{l}0.32 \\
1.70 \\
4.30 \\
3.76 \\
5.27 \\
2.41 \\
1.20 \\
1.04 \\
1.61\end{array}$ & $\begin{array}{l}0.39 \\
2.22 \\
4.21 \\
4.25 \\
4.65 \\
2.82 \\
1.68 \\
0.82 \\
3.61\end{array}$ & $\begin{array}{l}0.13 \\
0.63 \\
2.11 \\
3.11 \\
3.77 \\
3.10 \\
1.60 \\
0.60 \\
1.34\end{array}$ & $\begin{array}{r}0.02 \\
0.17 \\
0.38 \\
0.49 \\
2.63 \\
27.07 \\
3.36 \\
0.84 \\
0.20\end{array}$ & $\begin{array}{l}0.20 \\
1.17 \\
3.07 \\
3.43 \\
4.49 \\
3.13 \\
1.62 \\
1.22 \\
3.42\end{array}$ \\
\hline Sume & 20.82 & 23.03 & 23.55 & 21.61 & 24.65 & 16.39 & 35.10 & 21.75 \\
\hline \multicolumn{9}{|c|}{ Servicios } \\
\hline $\begin{array}{r}0-300 \\
301-600 \\
601-1000 \\
1001=1500 \\
1501=3000 \\
3000=4500 \\
4501=6000 \\
6001=10000 \\
\text { Más de } 10000\end{array}$ & $\begin{array}{l}4.50 \\
5.96 \\
8.25 \\
4.88 \\
7.79 \\
2.44 \\
1.04 \\
1.14 \\
0.47\end{array}$ & $\begin{array}{r}1.51 \\
3.27 \\
6.17 \\
5.57 \\
12.85 \\
5.97 \\
3.19 \\
5.61 \\
2.89\end{array}$ & $\begin{array}{r}2.21 \\
4.10 \\
7.10 \\
5.72 \\
10.97 \\
4.24 \\
2.11 \\
2.50 \\
1.19\end{array}$ & $\begin{array}{r}0.96 \\
2.90 \\
6.11 \\
5.85 \\
14.68 \\
6.30 \\
3.68 \\
5.49 \\
2.54\end{array}$ & $\begin{array}{r}1.57 \\
3.59 \\
6.74 \\
5.76 \\
15.13 \\
6.33 \\
4.20 \\
7.54 \\
4.03\end{array}$ & $\begin{array}{r}0.14 \\
1.27 \\
4.70 \\
5.66 \\
15.51 \\
5.84 \\
3.29 \\
11.80 \\
4.78\end{array}$ & $\begin{array}{r}0.01 \\
0.22 \\
0.90 \\
2.98 \\
14.27 \\
9.30 \\
1.78 \\
10.01 \\
9.53\end{array}$ & $\begin{array}{r}0.74 \\
2.25 \\
4.34 \\
5.18 \\
13.41 \\
9.21 \\
4.84 \\
9.36 \\
4.93\end{array}$ \\
\hline Sune & 36.47 & 46.97 & 40.14 & 48.51 & 54.89 & 52.99 & 49.00 & 54.26 \\
\hline
\end{tabular}

Fúnte: Banco de México, Oficina de Estudios sobre Proyecciones Agrícolas, Encuesta de ingresos y gastos familiares, 1963.

11 Citada en la nota 10. 
47 \%. (Véase el cuadro 10.) Tal como era de esperar, el consumo de alimentos $\mathrm{y}$ bebidas desciende como proporción del gasto familiar total conforme el ingreso medio de la familia aumenta. Mientras representa el $64.6 \%$ del ingreso de una familia con ingresos menores de 300 pesos mensuales, constituye apenas el $20.2 \%$ de una familia con ingresos superiores a los 10000 pesos mensuales. En cambio, la ropa y el calzado se mantienen en una proporción más o menos constante del ingreso: entre el $11.5 \mathrm{y}$ el $14.6 \%$ del total. Con el ai-mento del ingreso familiar ganan en importancia los gastos en alumbra io, habitación, vehículos, muebles, aparatos domésticos, seguros, pagos de hipotecas, ahorro y otros. En el consumo influye también el grado de urbanización, tanto por las mayores oportunidades de encontrar empleo en la industria y los servicios con ingresos más altos, como porque el patrón de consumo de la población urbana es distinto al de la rural. Esto es especialmente claro en el renglón de alimentos, bebidas y tabaco, en los que, a los mismos niveles de ingreso, los habitantes del campo gastan una mayor proporción que los de las ciudades, mientras que en las zonas urbanas son más importantes los gastos en alumbrado, habitación y otros servicios (médicos, profesionales, domésticos, etc.). Estas diferencias se reflejan en distintas elasticidades-ingreso del consumo de la población urbana y rural. (Véase el cuadro 11.)

\section{Cuadro 11}

MÉXICO: ELASTICIDADES-INGRESO DEL CONSUMO FAMILIAR, 1963

\begin{tabular}{lcc}
\hline \multicolumn{1}{c}{ Conceptos } & \multicolumn{2}{c}{ Población } \\
\cline { 2 - 3 } & Urbana & Rural \\
\hline Alimentos y bebidas & 0.782 & 0.827 \\
Ropa y calzado & 0.686 & 0.655 \\
Habitación, combustibles, etc. & 0.925 & 1.061 \\
Vehículos, muebles, aparatos domésticos, etc. & 0.679 & 0.585 \\
Otros gastos & 1.188 & 1.548 \\
Seguros, hipotecas, ahorro & 2.021 & 4.452 \\
\hline
\end{tabular}

Fuente: Citada en el cuadro 10.

El consumo de la población rural acusa una elasticidad-ingreso superior a la correspondiente a la urbana respecto a los bienes producidos por el sector agropecuario; en tanto que los habitantes de las ciudades muestran elasticidades más altas que las del sector rúral en gastos en ropa y calzado, vehículos, muebles y aparatos domésticos, es decir, en bienes producidos por el sector industrial. (Véase el cuadro 12.) Considerada la disparidad de elasticidades de los distintos sectores, y la distribución del ingreso entre ellos, un crecimiento equilibrado, en el sentido de que la oferta de mercancías. y servicios aumente a una tasa acorde con las elasticidades-ingreso de la demanda de los mismos, es compatible con un desarrollo del sector agropecuario menor que el del resto de la economía. Sin embargo, la condición de generador de divisas del sector agropecuario lo coloca en una situación estratégica de solución compleja, que depende de factores como 
Cuadro 12

MÉxico: Elasticidades-INGRESo DEL CONSL̀Mo FAMILIAR POR PRODUCTOS, 1963

\begin{tabular}{|c|c|c|c|c|c|c|c|c|c|c|}
\hline \multirow[b]{2}{*}{ Producto } & \multirow[b]{2}{*}{$\begin{array}{l}\text { Tipo de } \\
\text { función }\end{array}$} & \multirow{2}{*}{\multicolumn{2}{|c|}{ Constantes }} & \multirow{2}{*}{\multicolumn{2}{|c|}{$\begin{array}{l}\text { Errores es- } \\
\text { tándar }\end{array}$}} & \multirow{2}{*}{$\begin{array}{l}\text { Coefi- } \\
\text { clente } \\
\text { de co- } \\
\text { rrela- } \\
\text { ción }\end{array}$} & \multicolumn{4}{|c|}{ Elasticidades } \\
\hline & & & & & & & $\begin{array}{c}\text { Urbana } \\
1963\end{array}$ & $\begin{array}{l}\text { Rural } \\
1963\end{array}$ & $\begin{array}{l}\text { Total } \\
1963\end{array}$ & $\begin{array}{l}\text { Totel } \\
1975\end{array}$ \\
\hline $\begin{array}{l}\text { Maíz } \\
\text { Frijol } \\
\text { Trigo } \\
\text { Arroz } \\
\text { Raíces feculentas } \\
\text { Chile fresco } \\
\text { Verduras (total) } \\
\text { Jitomate fresco } \\
\text { Frutas (total) } \\
\text { Café en grano }\end{array}$ & $\begin{array}{r}\text { semi- } 10 g \\
\text { semi-log } \\
\text { log } \\
\text { semi-log } \\
\text { semi- } 10 g \\
\text { semi-log } \\
\text { log } \\
\text { log } \\
\text { log } \\
\text { semi-log }\end{array}$ & $\begin{array}{r}32.455 \\
5.309 \\
-0.130 \\
-0.081 \\
-0.159 \\
0.803 \\
-1.162 \\
-2.230 \\
-1.620 \\
0.046\end{array}$ & $\begin{array}{r}-4.125 \\
-0.551 \\
0.244 \\
0.139 \\
0.271 \\
-0.072 \\
0.449 \\
0.469 \\
1.019 \\
0.050\end{array}$ & $\begin{array}{l}1.851 \\
0.134 \\
0.165 \\
0.091 \\
0.178 \\
0.086 \\
0.139 \\
0.228 \\
1.540 \\
0.056\end{array}$ & $\begin{array}{l}0.317 \\
0.023 \\
0.031 \\
0.017 \\
0.033 \\
0.015 \\
0.024 \\
0.039 \\
0.287 \\
0.010\end{array}$ & $\begin{array}{r}-0.980 \\
-0.994 \\
0.945 \\
0.947 \\
0.947 \\
-0.880 \\
0.990 \\
0.977 \\
0.782 \\
0.869\end{array}$ & $\begin{array}{r}-0.392 \\
-0.239 \\
0.246 \\
0.189 \\
0.188 \\
-0.074 \\
0.358 \\
0.342 \\
0.240 \\
0.151\end{array}$ & $\begin{array}{r}-0.294 \\
-0.112 \\
0.189 \\
0.236 \\
0.240 \\
-0.193 \\
0.435 \\
0.428 \\
0.280 \\
0.186\end{array}$ & $\begin{array}{r}-0.408 \\
-0.237 \\
0.244 \\
0.207 \\
0.207 \\
-0.174 \\
0.449 \\
0.469 \\
0.261 \\
0.158\end{array}$ & $\begin{array}{r}-0.465 \\
-0.256 \\
0.244 \\
0.195 \\
0.195 \\
-0.184 \\
0.449 \\
0.469 \\
0.242 \\
0.151\end{array}$ \\
\hline $\begin{array}{l}\text { Carne } \\
\text { Leche frosca } \\
\text { Huevos } \\
\text { Manteca animal } \\
\text { Mantequilla } \\
\text { Pescados y martscos }\end{array}$ & $\begin{array}{l}\text { semi-log } \\
\text { semi-log } \\
\text { semi-log } \\
\text { semi-log } \\
\text { semi-log } \\
\text { semi-log }\end{array}$ & $\begin{array}{r}-7.561 \\
-16.062 \\
-0.279 \\
0.048 \\
-0.951 \\
-9.677\end{array}$ & $\begin{array}{l}1.794 \\
4.266 \\
0.209 \\
0.060 \\
0.198 \\
2.186\end{array}$ & $\begin{array}{l}0.174 \\
1.889 \\
0.261 \\
0.072 \\
0.133 \\
1.442\end{array}$ & $\begin{array}{l}0.030 \\
0.324 \\
0.049 \\
0.0133 \\
0.185 \\
0.247\end{array}$ & $\begin{array}{l}0.999 \\
0.980 \\
0.835 \\
0.853 \\
0.957 \\
0.958\end{array}$ & $\begin{array}{l}0.524 \\
0.429 \\
0.220 \\
0.129 \\
0.775 \\
0.680\end{array}$ & $\begin{array}{r}0.888 \\
0.618 \\
0.269 \\
0.243 \\
11.531 \\
2.102\end{array}$ & $\begin{array}{l}0.832 \\
0.605 \\
0.245 \\
0.161 \\
1.624 \\
1.010\end{array}$ & $\begin{array}{l}0.665 \\
0.512 \\
0.228 \\
0.154 \\
1.091 \\
0.775\end{array}$ \\
\hline $\begin{array}{l}\text { Pan (blanco y dulce) } \\
\text { Azúcar } \\
\text { Aceite vegetal } \\
\text { Leche evaporada } \\
\text { Grasas y aceltes } \\
\text { Café soluble } \\
\text { Chocolate } \\
\text { Cerveza } \\
\text { Tabaco }\end{array}$ & $\begin{array}{l}\text { semi-log } \\
\text { semi-log } \\
\text { semi-log } \\
\text { log inv. } \\
\text { log } \\
\text { semi- } 10 g \\
\text { semi- } 10 g \\
\text { semi- } 10 \mathrm{~g} \\
\text { log }\end{array}$ & $\begin{array}{r}-0.372 \\
0.006 \\
-0.178 \\
-0.605 \\
-0.359 \\
-9.140 \\
-0.477 \\
-2.147 \\
-2.728\end{array}$ & $\begin{array}{l}0.556 \\
0.312 \\
0.119 \\
478.4 \\
0.449 \\
1.883 \\
0.301 \\
0.726 \\
0.699\end{array}$ & $\begin{array}{l}0.406 \\
0.091 \\
0.170 \\
0.311 \\
0.271 \\
1.292 \\
0.477 \\
1.878 \\
0.382\end{array}$ & $\begin{array}{l}0.076 \\
0.017 \\
0.032 \\
57.90 \\
0.049 \\
0.221 \\
0.089 \\
1.322 \\
0.066\end{array}$ & $\begin{array}{l}0.935 \\
0.990 \\
0.800 \\
0.946 \\
0.961 \\
0.955 \\
0.769 \\
0.649 \\
0.971\end{array}$ & $\begin{array}{l}0.190 \\
0.172 \\
0.226 \\
0.965 \\
0.273 \\
0.868 \\
0.251 \\
0.284 \\
0.699\end{array}$ & $\begin{array}{l}0.232 \\
0.190 \\
0.236 \\
3.235 \\
0.322 \\
4.982 \\
0.194 \\
0.171 \\
0.222\end{array}$ & $\begin{array}{l}0.211 \\
0.184 \\
0.255 \\
2.125 \\
0.449 \\
1.777 \\
0.261 \\
0.406 \\
0.699\end{array}$ & $\begin{array}{l}0.198 \\
0.174 \\
0.237 \\
1.573 \\
0.449 \\
1.158 \\
0.242 \\
0.362 \\
0.699 \\
\text { (Cont }\end{array}$ \\
\hline
\end{tabular}


Cuadro 12 (Continuación)

\begin{tabular}{|c|c|c|c|c|c|c|c|c|c|c|}
\hline \multirow{3}{*}{ Producto } & \multirow{3}{*}{$\begin{array}{l}\text { Tipo de } \\
\text { función }\end{array}$} & \multirow{2}{*}{\multicolumn{2}{|c|}{ Constantes }} & \multirow{2}{*}{\multicolumn{2}{|c|}{$\begin{array}{c}\text { Errores es- } \\
\text { tándar }\end{array}$}} & \multirow{3}{*}{$\begin{array}{l}\text { Coefi- } \\
\text { ciente } \\
\text { de co- } \\
\text { rrela- } \\
\text { ción }\end{array}$} & \multicolumn{4}{|c|}{ Elasticidades } \\
\hline & & & & & & & Urbana & Rural & Total & Tot8I \\
\hline & & A & B & A & B & & 1963 & 1963 & 1963 & 1975 \\
\hline Rope y calzado & 108 & -0.271 & 0.691 & 0.260 & 0.049 & 0.981 & 0.686 & 0.655 & 0.691 & 0.691 \\
\hline $\begin{array}{l}\text { Ropa y telas de } \\
\text { algodón } \\
\text { Artículos textiles }\end{array}$ & $\log$ & -0.167 & 0.538 & 0.161 & 0.030 & 0.988 & 0.532 & 0.550 & 0.538 & 0.538 \\
\hline & $\begin{array}{r}\operatorname{sem} 1-\log \\
\log \end{array}$ & $\begin{array}{l}-0.796 \\
-1.148\end{array}$ & $\begin{array}{l}0.460 \\
0.445\end{array}$ & $\begin{array}{l}0.819 \\
1.079\end{array}$ & $\begin{array}{l}0.253 \\
0.201\end{array}$ & $\begin{array}{l}0.732 \\
0.616\end{array}$ & $\begin{array}{l}0.252 \\
0.454\end{array}$ & $\begin{array}{l}0.284 \\
0.317\end{array}$ & $\begin{array}{l}0.271 \\
0.445\end{array}$ & $\begin{array}{l}0.251 \\
0.445\end{array}$ \\
\hline $\begin{array}{l}\text { Ropa de otros mate- } \\
\text { riales } \\
\text { Calzado } \\
\text { Otros artículos de }\end{array}$ & $\begin{array}{l}\log \\
\log \end{array}$ & $\begin{array}{l}-8.724 \\
-0.391\end{array}$ & $\begin{array}{l}1.791 \\
0.440\end{array}$ & $\begin{array}{l}1.007 \\
0.392\end{array}$ & $\begin{array}{l}0.173 \\
0.073\end{array}$ & $\begin{array}{l}0.969 \\
0.906\end{array}$ & $\begin{array}{l}1.191 \\
0.443\end{array}$ & $\begin{array}{l}1.862 \\
0.396\end{array}$ & $\begin{array}{l}1.791 \\
0.440\end{array}$ & $\begin{array}{l}1.791 \\
0.440\end{array}$ \\
\hline cuero y piel & $\log$ & -3.580 & 0.653 & 0.726 & 0.124 & 0.893 & 0.751 & 0.615 & 0.653 & 0.653 \\
\hline Habitación, combusti- & & & & & & & & & & \\
\hline ble & $\log$ & -3.055 & 1.200 & 0.263 & 0.045 & 0.995 & 0.925 & 1.061 & 1.200 & 1.200 \\
\hline$\frac{\text { Vehículos, muebles, }}{\text { aparatos }}$ & $\log$ & -1.123 & 0.663 & 1.059 & 0.198 & 0.765 & 0.679 & 0.585 & 0.663 & 0.663 \\
\hline Otros gastos & $\log$ & -4.452 & 1.490 & 0.325 & 0.056 & 0.995 & 1.188 & 1.548 & 1.490 & 1.490 \\
\hline$\frac{\text { Seguros, hipotecas, }}{\text { ahorro }}$ & $\log$ & -14.408 & 2.737 & 2.196 & 0.377 & 0.940 & 2.021 & 4.452 & 2.737 & 2.737 \\
\hline
\end{tabular}

Fuente: Citada en el cuadro 10. 
la relación de intercambio, la sustitución de importaciones y el cambio tecnológico. Las elasticidades-ingreso y el crecimiento del sector agropecuario sugieren también la idea de que la creación de presiones inflacionarias por inelasticidad de la oferta de alimentos, como se ha señalado frecuentemente para otros países, es poco probable en el caso de México.

La disparidad de elasticidades ayuda a explicar el cambio estructural del producto, en el que el sector agropecuario significó en 1940 el $23.3 \%$ del producto bruto interno y en 1962 sólo el $17.2 \%$ del total.

La inversión y el ahorro. La inversión se modificó también al aumentar su contenido de bienes producidos internamente, y su efecto en el producto interno se alteró. La influencia de la inversión en el desarrollo sectorial del producto no se puede precisar a causa de las deficiencias de las estadísticas de inversión, inventarios y capital fijo. Sin embargo, el fortalecimiento de la base productiva se ha debido, cuando menos en parte, a una deliberada política gubernamental, según puede observarse en el cuadro 13.

\section{Cuadro 13}

MÉxico: CRECIMIENTO DEL.PROdUCTO BRUTO INTERNO Y DE LA INVERSIÓN BRUTA FIJA, 1940 a 1960

$(1945=100$, calculado sobre cifras en millones de pesos de 1960)

\begin{tabular}{llllll}
\hline & 1940 & 1945 & 1950 & 1955 & 1960 \\
\hline Producto bruto interno & 71.7 & 100.0 & 134.3 & 180.7 & 244.4 \\
Inversión total & 47.0 & 100.0 & 127.9 & 147.6 & 192.5 \\
Inversión pública & 49.6 & 100.0 & 150.4 & 140.6 & 192.4 \\
$\quad$ Fomento agropecuario & 44.5 & 100.0 & 176.4 & 117.5 & 181.8 \\
Fomento industrial & 65.9 & 100.0 & 297.2 & 368.3 & 430.5 \\
Fomento de servicios & 47.8 & 100.0 & 119.5 & 102.5 & 173.6 \\
Inversión privada & 45.2 & 100.0 & 111.3 & 152.8 & 192.5 \\
\hline
\end{tabular}

Fuente: Grupo Técnico Secretaría de Hacienda-Banco de México.

Se puede examinar el efecto de la inversión en la producción mediante la observación de la relación capital-producto. Sus desplazamientos indican, de manera gruesa, la influencia en la demanda global, así como las necesidades de inversión para mantener el crecimiento sostenido. Con frecuencia se señala que a principios del proceso de desarrollo la relación producto-capital desciende como resultado de la inversión en obras de infraestructura con largos periodos de gestación y vida productiva, que sin embargo son esenciales para promover la produción de energía y la integración del mercado interno que constituyen condiciones previas del desarrollo sostenido. Por otro lado, esta tendencia general puede no operar, e inclusive la relación productocapital puede ascender, como resultado del crecimiento rápido de la fuerza de trabajo, del empleo de procesos productivos que usan mayores proporciones de mano de obra, del aumento de la productividad de la fuerza de trabajo o del capital, o por cambios en la estructura de 
la inversión que favorezcan actividades con menor período de gestación. Aunque no se conoce la distribución sectorial de la inversión privada, que indicaría los posibles cambios de estructura, se sabe que la productividad aumenta en aquellas épocas de comportamiento muy dinámico de la inversión. Sin embargo, parece que esto no sucede en el caso de nuestro estudio. De hecho, algunos autores han señalado que la relación producto-capital bajó en 1941-1945 cuando la inversión pública y la privada, según un criterio reducido que excluye inventarios y gastos de mantenimiento, ascendieron 15.1 y $17.2 \%$ al año respectivamente. ${ }^{12}$ En cambio, la relación subió cuando la tasa de crecimiento de la inversión fue lenta, como sucedió en el período 1951-1960, en el cual creció al $4.7 \%$ anual.

La inversión privada muestra un comportamiento cíclico que influye en el nivel de las importaciones y en el déficit en cuenta corriente de la balanza de pagos. Este último compensa el efecto de las modificaciones de la inversión en el ingreso. En realidad, las importaciones de bienes y servicios están asociadas en forma directa con la inversión privada y se desplazan de acuerdo con ella. El saldo en cuenta corriente compensa el efecto en el ingreso de los cambios de la inversión privada y muestra la capacidad del sistema para generar oscilaciones cíclicas, en tanto la inversión privada esté determinada por causas internas.

\section{LOS CAMBIOS EN LA PRODUCCIÓN}

La disparidad de las tasas de crecimiento de los distintos sectores productivos obedece a la asimetría de los estímulos de la demanda interna y externa y a la adopción de las medidas de política económica tendientes a diversificar el crecimiento económico del país y darle base más firme y estable.

El crecimiento sectorial. La participación de la producción manufacturera en el producto bruto interno de 1940 a 1962 pasó de 17.8 a $23.3 \%$. El cambio proporcional fue también marcado en los renglones dependientes de la inversión pública de carácter autónomo o independiente de cambios a corto plazo del nivel del ingreso: la generación de energía eléctrica y la extracción, refinamiento y distribución de petróleo y derivados, que conjuntamente avanzaron del 3.7 al $4.5 \%$ del total. Estos han constituido estabilizadores del crecimiento económico. (Véase el cuadro 14.)

El caso más notable de baja lo constituye la minería, que perdió importancia relativa inclusive a lo largo de la segunda Guerra Mundial, cuando, a pesar de las excepcionales condiciones de la demanda externa de minerales, creció a una tasa del $1.1 \%$ anual, frente al $6.9 \%$ en que aumentó el producto total. Con el empeoramiento posterior de la condición del mercado de los minerales en el ámbito internacional, la tasa anual de aumento de este sector descendió, habiendo llegado en todo el período 1941-1960 a sólo 0.9\%. Otro sector con descenso relativo fue el agropecuario, que disminuyó como resultado de la baja absoluta

12 Luis Cossio y Rafael Izquierdo, "Estimación de la relación producto-capital de México, 19401960", El Trimestre Económico, Vol. XXIX, Núm. 116, México, 1962. 
Cuadro 14

MÉXICO: PaRTICIPACIÓN DE LOS SECTORES DE LA PRODUCCIÓN EN EL PRODUCTO BRUTO INTERNO, 1940 a 1962

(Porcientos del total, sobre cifras a precios de 1960)

\begin{tabular}{lrrrrr}
\hline & 1940 & \multicolumn{1}{c}{1945} & \multicolumn{1}{c}{1950} & 1955 & 1962 \\
\hline Total & 100.0 & 100.0 & 100.0 & 100.0 & 100.0 \\
Producción agropecuaria & 23.2 & 18.6 & 20.8 & 20.3 & 17.2 \\
Agrícola & 10.6 & 9.9 & 12.3 & 12.8 & 10.4 \\
Ganadera & 11.0 & 7.7 & 7.5 & 6.7 & 6.3 \\
Forestal & 1.5 & 0.8 & 0.8 & 0.6 & 0.3 \\
Pesca & 0.1 & 0.2 & 0.2 & 0.2 & 0.2 \\
Producción industrial & 31.0 & 34.0 & 31.0 & 31.3 & 33.9 \\
Manufacturas & 17.8 & 20.8 & 20.7 & 21.1 & 23.3 \\
Minería & 4.6 & 3.5 & 2.4 & 2.2 & 1.6 \\
Electricidad & 0.9 & 0.8 & 0.9 & 1.0 & 1.3 \\
Petróleo & 2.8 & 2.4 & 2.7 & 2.7 & 3.2 \\
Construcción & 4.9 & 6.5 & 4.3 & 4.3 & 4.5 \\
Servicios & 45.8 & 47.4 & 48.2 & 48.4 & 48.9 \\
Transportes & 4.0 & 4.1 & 4.4 & 4.7 & 4.1 \\
Comercio & 24.7 & 26.1 & 26.5 & 26.1 & 25.9 \\
Gobierno & 3.3 & 3.5 & 3.4 & 3.1 & 3.0 \\
Otras actividades & 13.8 & 13.7 & 13.9 & 14.5 & 15.9 \\
\hline
\end{tabular}

Fuentes: Citadas en el cuadro 15.

en la silvicultura y el débil aumento de la ganadería. Esto último puede ser motivo de seria preocupación a causa de las elevadas elasticidadesingreso de los productos pecuarios. También perdió importancia relativa el sector de la construcción, el cual sólo recientemente ha mostrado una aceleración en su tasa de crecimiento, alcanzando el $8.1 \%$ en 1956-1960. (Véase el cuadro 15.)

El desarrollo industrial. La orientación del proceso de industrialización de México ha consistido en atender preferentemente el mercado interno. Esta orientación es el resultado del atraso general respecto a los países avanzados y del tipo de política de fomento industrial seguido hasta la fecha: exención de impuestos, facilidades de acceso al mercado de dinero y capitales, y franquicias de diversa índole para el establecimiento de nuevas industrias con objeto de ampliar en la forma más rápida posible la base industrial del país. Se ha recurrido también a la protección arancelaria y al establecimiento de contingentes de importación con objeto de proteger la creciente industria. $\mathrm{La}$ interacción de esas fuerzas se aprecia en las tasas de crecimiento del sector y en el cambio estructural que se ha señalado.

La protección al proceso de desarrollo industrial ha alterado la posición de costos de los productores, afectando aun a los más eficientes y limitando la posición competitiva general. Este razonamiento, que expresa conjeturas no bien fundamentadas, se àpoya en indicios 


\section{Cuadro 15}

México: Producto bruto INTERNo y población eCONÓMICAMENTE ACTIVA POR SECTORES, 1939-1962 (Millones de pesos de 1960)

\begin{tabular}{|c|c|c|c|c|c|c|c|c|c|c|c|c|c|c|c|c|}
\hline \multirow[b]{2}{*}{ Años } & \multicolumn{3}{|c|}{ Agricultura } & \multicolumn{3}{|c|}{ Industria } & \multicolumn{3}{|c|}{ Servicios } & \multicolumn{3}{|c|}{ Total } & \multicolumn{4}{|c|}{ Tasas de crecimlento anual } \\
\hline & $\begin{array}{l}\text { Pobla- } \\
\text { ctón } \\
\text { activa }\end{array}$ & $\begin{array}{c}\text { Produc } \\
\text { to }\end{array}$ & $\begin{array}{l}\text { Produc } \\
\text { to por } \\
\text { perso- } \\
\text { na }\end{array}$ & $\begin{array}{l}\text { Poblá- } \\
\text { clón } \\
\text { activa }\end{array}$ & $\begin{array}{c}\text { Produc } \\
\text { to }\end{array}$ & $\begin{array}{c}\text { Produc } \\
\text { to por } \\
\text { perso- } \\
\text { ne }\end{array}$ & $\begin{array}{l}\text { Pobla- } \\
\text { c1́ón } \\
\text { activa }\end{array}$ & $\begin{array}{c}\text { Produc } \\
\text { to }\end{array}$ & $\begin{array}{l}\text { Produc } \\
\text { to por } \\
\text { perso- } \\
\text { na }\end{array}$ & $\begin{array}{l}\text { Pobla- } \\
\text { clón } \\
\text { active }\end{array}$ & $\begin{array}{c}\text { Produc } \\
\text { to }\end{array}$ & $\begin{array}{l}\text { Produc } \\
\text { to por } \\
\text { perso- } \\
\text { na }\end{array}$ & $\begin{array}{l}\text { Agrom } \\
\text { pecue } \\
\text { ria }\end{array}$ & $\begin{array}{l}\text { Indus } \\
\text { trial }\end{array}$ & & Total \\
\hline $\begin{array}{l}1939 \\
1940 \\
1941 \\
1942 \\
1943 \\
1944 \\
1945 \\
1946 \\
1947 \\
1948 \\
1949 \\
1950 \\
1951 \\
1952 \\
1953 \\
1954 \\
1955 \\
1956 \\
1957 \\
1958 \\
1959 \\
1960 \\
1961 \\
1962 \\
\text { Tasas med }\end{array}$ & $\begin{array}{rr}3 & 830.9 \\
3 & 920.2 \\
4 & 011.6 \\
4 & 105.1 \\
4 & 200.9 \\
4 & 298.8 \\
4 & 399.0 \\
4 & 501.6 \\
4 & 606.6 \\
4 & 714.0 \\
4 & 823.9 \\
4 & 942.1 \\
5 & 063.2 \\
5 & 187.2 \\
5 & 134.3 \\
5 & 444.5 \\
5 & 577.9 \\
5 & 714.5 \\
5 & 854.6 \\
5 & 998.0 \\
6 & 144.9 \\
6 & 231.3 \\
6 & 319.0 \\
\text { tas de cre }\end{array}$ & $\begin{array}{rr}9 & 554 \\
9 & 469 \\
10 & 386 \\
11 & 244 \\
11 & 064 \\
11 & 241 \\
10 & 625 \\
11 & 316 \\
12 & 297 \\
13 & 058 \\
14 & 416 \\
16 & 052 \\
16 & 940 \\
16 & 566 \\
16 & 522 \\
19 & 263 \\
20 & 992 \\
20 & 541 \\
22 & 246 \\
23 & 804 \\
23.076 \\
24 & 276 \\
24 & 966 \\
26 & 236 \\
2 \text { cimiento } \\
\end{array}$ & $\begin{array}{ll}2 & 472 \\
2 & 649 \\
2 & 803 \\
2 & 695 \\
2 & 676 \\
2 & 472 \\
2 & 572 \\
2 & 732 \\
2 & 835 \\
3 & 058 \\
3 & 328 \\
3 & 428 \\
3 & 074 \\
3 & 185 \\
3 & 625 \\
3 & 856 \\
3 & 683 \\
3 & 893 \\
4 & 066 \\
3 & 847 \\
3 & 951 \\
4 & 007 \\
4 & 152 \\
0 & \end{array}$ & $\begin{array}{ll} & 746.6 \\
788.0 \\
832.5 \\
880.1 \\
931.0 \\
985.4 \\
1 \\
1 & 043.5 \\
1 & 105.7 \\
1 & 172.2 \\
1 & 243.2 \\
1 & 319.2 \\
1 & 384.9 \\
1 & 453.9 \\
1 & 526.4 \\
1 & 602.6 \\
1 & 682.1 \\
1 & 766.3 \\
1 & 853.0 \\
1 & 947.9 \\
2 & 045.5 \\
2 & 148.0 \\
2 & 227.5 \\
2 & 310.2\end{array}$ & $\begin{array}{ll}12 & 683 \\
12 & 802 \\
14 & 258 \\
16 & 054 \\
16 & 886 \\
17 & 906 \\
19 & 490 \\
19 & 514 \\
19 & 975 \\
20 & 614 \\
21 & 701 \\
23 & 909 \\
26 & 125 \\
27 & 741 \\
27 & 307 \\
29 & 529 \\
32 & 564 \\
36 & 070 \\
38 & 785 \\
40 & 448 \\
43 & 865 \\
47 & 479 \\
49 & 232 \\
51 & 689\end{array}$ & $\begin{array}{ll}17 & 147 \\
18 & 084 \\
20 & 245 \\
19 & 186 \\
19 & 233 \\
19 & 779 \\
17 & 064 \\
18 & 069 \\
17 & 586 \\
17 & 445 \\
18 & 130 \\
18 & 868 \\
19 & 075 \\
17 & 899 \\
18 & 426 \\
19 & 358 \\
20 & 421 \\
20 & 939 \\
20 & 764 \\
21 & 357 \\
22 & 082 \\
22 & 101 \\
22 & 374\end{array}$ & $\begin{array}{ll}1 & 280.9 \\
1 & 336.3 \\
1 & 396.4 \\
1 & 461.9 \\
1 & 533.3 \\
1 & 611.3 \\
1 & 696.5 \\
1 & 790.0 \\
1 & 892.5 \\
2 & 005.1 \\
2 & 129.0 \\
1 & 918.7 \\
2 & 019.1 \\
2 & 124.9 \\
2 & 230.1 \\
2 & 353.4 \\
2 & 476.7 \\
2 & 606.7 \\
2 & 743.4 \\
2 & 887.5 \\
3 & 039.1 \\
3 & 170.7 \\
3 & 308.3\end{array}$ & $\begin{array}{ll}18 & 773 \\
18 & 841 \\
21 & 468 \\
22 & 820 \\
23 & 812 \\
26 & 230 \\
27 & 244 \\
29 & 597 \\
30 & 886 \\
30 & 988 \\
33 & 368 \\
37 & 046 \\
39 & 932 \\
42 & 104 \\
42 & 656 \\
46 & 558 \\
50 & 066 \\
54 & 303 \\
58 & 322 \\
61 & 488 \\
62 & 838 \\
68 & 410 \\
70 & 933 \\
74 & 350\end{array}$ & $\begin{array}{ll}14 & 708 \\
16 & 065 \\
16 & 341 \\
16 & 288 \\
17 & 106 \\
16 & 908 \\
17 & 445 \\
16 & 08 \\
16 & 461 \\
16 & 641 \\
17 & 400 \\
20 & 812 \\
20 & 854 \\
20 & 017 \\
20 & 762 \\
21 & 782 \\
21 & 865 \\
22 & 317 \\
22 & 353 \\
23 & 629 \\
22 & 509 \\
22 & 352 \\
22 & 437\end{array}$ & $\begin{array}{rr}5 & 858.4 \\
6 & 044.4 \\
6 & 240.5 \\
6 & 447.1 \\
6 & 665.1 \\
6 & 895.5 \\
7 & 139.1 \\
7 & 397.3 \\
7 & 671.2 \\
7 & 962.3 \\
8 & 272.1 \\
8 & 245.7 \\
8 & 536.2 \\
8 & 838.5 \\
9 & 147.0 \\
9 & 480.0 \\
9 & 820.9 \\
10 & 174.2 \\
10 & 545.9 \\
10 & 930.9 \\
11 & 332.0 \\
11 & 629.6 \\
11 & 937.5\end{array}$ & 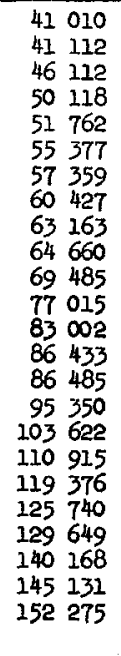 & $\begin{array}{rr}7 & 017.6 \\
7 & 629.0 \\
8 & 031.0 \\
8 & 029.0 \\
8 & 308.0 \\
8 & 319.0 \\
8 & 464.0 \\
8 & 539.0 \\
8 & 429.0 \\
9 & 839.0 \\
9 & 310.0 \\
10 & 066.0 \\
10 & 125.0 \\
9 & 778.0 \\
10 & 410.0 \\
10 & 992.0 \\
11 & 285.0 \\
11 & 725.0 \\
11 & 914.0 \\
11 & 852.0 \\
12 & 369.0 \\
12 & 477.0 \\
12 & 750.0\end{array}$ & $\begin{array}{r}-0.9 \\
9.7 \\
8.3 \\
-1.6 \\
1.6 \\
-5.5 \\
6.5 \\
8.7 \\
6.2 \\
10.4 \\
11.3 \\
5.5 \\
-0.2 \\
-0.3 \\
16.6 \\
9.0 \\
-2.2 \\
8.3 \\
7.0 \\
-3.1 \\
5.2 \\
2.8 \\
5.1\end{array}$ & $\begin{array}{r}0.9 \\
11.4 \\
12.6 \\
5.2 \\
6.0 \\
8.8 \\
0.1 \\
2.4 \\
3.2 \\
5.3 \\
10.2 \\
9.3 \\
6.2 \\
-1.6 \\
8.1 \\
10.3 \\
10.8 \\
7.5 \\
4.3 \\
8.4 \\
8.2 \\
3.7 \\
5.0\end{array}$ & $\begin{array}{r}0.4 \\
13.9 \\
6.3 \\
4.3 \\
10.2 \\
3.9 \\
8.6 \\
4.4 \\
0.3 \\
7.7 \\
11.0 \\
7.8 \\
6.7 \\
1.3 \\
9.1 \\
7.5 \\
8.5 \\
7.4 \\
5.4 \\
2.3 \\
8.8 \\
3.7 \\
4.8\end{array}$ & $\begin{array}{r}0.2 \\
1.2 .2 \\
8.7 \\
3.3 \\
7.0 \\
3.6 \\
5.3 \\
4.5 \\
2.4 \\
7.5 \\
10.8 \\
7.8 \\
4.1 \\
0.1 \\
10.3 \\
8.7 \\
7.0 \\
7.6 \\
5.3 \\
3.1 \\
8.1 \\
3.5 \\
4.9\end{array}$ \\
\hline $\begin{array}{l}1941-45 \\
1946-50 \\
1951-55 \\
1956-60\end{array}$ & $\begin{array}{r}9.7 \\
9.7 \\
10.2 \\
10.2\end{array}$ & $\begin{array}{r}2.3 \\
41.9 \\
23.9 \\
18.2\end{array}$ & $\begin{array}{r}0.0 \\
29.4 \\
12.5 \\
7.3\end{array}$ & $\begin{array}{l}25.1 \\
26.4 \\
21.5 \\
21.6\end{array}$ & $\begin{array}{l}36.7 \\
22.5 \\
24.6 \\
31.6\end{array}$ & $\begin{array}{l}9.4 \\
6.2 \\
2.6 \\
8.1\end{array}$ & $\begin{array}{l}20.6 \\
25.5 \\
22.7 \\
22.7\end{array}$ & $\begin{array}{l}26.9 \\
25.2 \\
25.4 \\
26.0\end{array}$ & $\begin{array}{r}5.2 \\
-0.3 \\
4.7 \\
2.9\end{array}$ & $\begin{array}{l}14.1 \\
15.9 \\
15.0 \\
15.4\end{array}$ & $\begin{array}{l}24.4 \\
27.5 \\
24.8 \\
26.4\end{array}$ & $\begin{array}{r}9.0 \\
10.0 \\
9.2 \\
9.6\end{array}$ & $\begin{array}{l}2.5 \\
8.6 \\
6.1 \\
3.0\end{array}$ & $\begin{array}{l}8.8 \\
4.2 \\
6.5 \\
7.8\end{array}$ & $\begin{array}{l}7.7 \\
6.4 \\
6.5 \\
6.5\end{array}$ & $\begin{array}{l}7.0 \\
6.1 \\
6.2 \\
5.2\end{array}$ \\
\hline $1940-62$ & 64.9 & $1.77 \cdot 1$ & 68.0 & 209.4 & 303.8 & 30.5 & 158.3 & 294.6 & 52.5 & 103.8 & 270.4 & 76.3 & 4.4 & 5.4 & 6.2 & 5.9 \\
\hline
\end{tabular}

Fuente: Grupo Secretaría de Hacienda-Banco de México, Estudios sobre proyecciones, Manual de estadisticas básicas para análisis $y$ proyecciones del desarrollo económico de México, julio de 1964. 
de diversa índole, tales como el bajo porcentaje de bienes industriales que se exportan, y en que la protección va en aumento porque se opera con costos crecientes y más elevados que en el exterior. El coeficiente medio teórico de aranceles que pagaban los productos manufacturados era de $32.7 \%$ en 1960 , en tanto que a los comestibles y materiales crudos, en su mayoría agrícolas, se les aplicaba el 15.9 y el $22.0 \%$ al ser exportados - sin considerar los subsidios. De manera que mientras unos necesitan protección, otros son competitivos aún después de pagar impuestos a la exportación bastante onerosos. El impacto debe de ser aún más serio en el caso de los permisos de importación. Además, la protección en etapas primarias del proceso productivo eleva el precio de los insumos, piramida el alza de costos y dificulta las posibilidades de exportación.

Dentro del valor exportado han perdido importancia los minerales y la han ganado los productos agrícolas con efectos inducidos distintos, ya que en tanto que los minerales contienen una fuerte proporción de recursos naturales que explotan principalmente compañias extranjeras, los productos de la agricultura altamente tecnificada y, recientemen. te, los manufacturados, poseen menor contenido de mano de obra y de recursos naturales, mayor contenido de capital y un valor retenido internamente superior (valor agregado menos valor remitido al exterior como pago a los factores), toda vez que pertenece a empresas mexicanas. En este aspecto ha sido especialmente importante la diversificación de las exportaciones, debido en mucho al crecimiento del sector agropecuario y de los servicios frente a la minería, que han amortiguado las oscilaciones cíclicas del exterior y que por su mayor va!or interno han acentuado su efecto inducido en el ingreso y el gasto internos. (Véase, antes, el cuadro 3.)

El intenso desarrollo industrial origina un proceso de sustitución de importaciones que ha alterado la composición de las mismas. (Véase el cuadro 16.) Es evidente que el proceso de sustitución de importaciones ha reducido el porcentaje importado de bienes de consumo tales como textiles, calzado, prendas de vestir, alimentos, bebidas y tabaco. También han sido sustituidos algunos productos intermedios y bienes de inversión, tales como los empaques y envases, artículos

\section{Cuadro 16}

MÉxico: Composición de las IMPORTACIONES, 1900 a $1962^{\text {a }}$

(Porcientos del total)

\begin{tabular}{lrrrrrrr}
\hline \multicolumn{1}{c}{ Concepto } & 1900 & 1910 & 1940 & 1945 & 1950 & 1955 & 1962 \\
\hline Importaciones totales & 100.0 & 100.0 & 100.0 & 100.0 & 100.0 & 100.0 & 100.0 \\
Bienes de consumo & 39.1 & 44.0 & 22.6 & 20.6 & 14.9 & 14.4 & 12.9 \\
Combustibles y lubricantes & & & 2.7 & 2.8 & 4.3 & 8.1 & 2.5 \\
Materias primas & 29.5 & 26.0 & 38.9 & 35.5 & 36.2 & 34.1 & 41.8 \\
Bienes de capital & 31.4 & 30.0 & 35.0 & 40.4 & 44.0 & 43.2 & 42.6 \\
\hline
\end{tabular}


para la construcción e instalaciones, celulosa y papel, productos químicos, hierro y acero, etcétera.

A juzgar por las cifras disponibles, el impacto del sector externo ha disminuido. Por un lado, la sustitución de importaciones; por otro, la mayor importancia de la agricultura y del turismo cuyo valor retenido internamente es superior al de los sectores minero, petrolero o industrial en general. Esto ha constituido formas de aislar al sector interno del externo. ${ }^{13}$

La producción agrícola y el desarrollo general. El tipo de desenvolvimiento industrial que México ha seguido asigna tareas bien definidas al sector agrícola. Como la producción industrial demanda divisas para su normal desarrollo y no crea la oferta de las mismas para pagar las importaciones y efectuar el servicio de la deuda correspondiente, el sector agrícola tiene tareas específicas que cumplir si es que el país ha de observar un crecimiento sostenido: debe producir alimentos para el consumo del sector agropecuario y de la población ocupada en otras actividades; debe producir bienes intermedios para la industria, y debe generar un excedente exportable suficientemente grande como para cubrir el valor de las importaciones de bienes de, producción que se usan en la capitalización del país y el de las adquisiciones en el exterior de materias primas utilizadas en la producción industrial. En este aspecto encontró apoyo en los ingresos de divisas provenientes del turismo y en el incremento del valor retenido internamente.

El sector agrícola mantuvo un crecimiento bastante rápido de 1946 a 1955 y experimentó un serio estancamiento en el quinquenio 1956-1960. Es indudable que de 1941 a 1955 la producción agrícola para exportación fue un importante renglón de obtención de divisas; basta señalar que frente a exportaciones totales de mercancías que en 1941-1960 crecieron a una tasa media anual de $4.4 \%$, las exportaciones de productos agrícolas y forestales lo hicieron a una tasa de $9.1 \%$ y contribuyeron vigorosamente al aumento de la capacidad para importar, modificando además la estructura de las exportaciones.

En la agricultura mexicana se advierte un carácter dual. Por un lado, están la agricultura comercial de los distritos de riego y la ganadería especializada, con productividad elevada y en aumento y con capacidad para absorber cambios tecnológicos y hacer uso de insumos que elevan la productividad por hectárea; por otro, la agricultura de subsistencia, que carece de la suficiente flexibilidad para adoptar nuevas técnicas y en la que el crecimiento demográfico presiona cada vez más los recursos. Existen marcadas diferencias en la productividad por hectárea, la que depende de la importancia de uno u otro tipo de cultivo en cada región.

Durante el período 1946-1956, la tasa de crecimiento de la producción agropecuaria excedió a la del producto, sobre todo durante el auge algodonero y en la época de la fuerte expansión de las superficies de riego. Como la elasticidad-ingreso de los productos agropecuarios es bastante menor que la unidad, se originó un excedente para exporta-

13 Véase el trabajo de Antonio Aspra, La transmisión de las fluctuaciones cí. clicas a la economia mexicana, tesis, UNAM, Escuela Nacional de Economía, México, 1965. 
ción bastante importante. La producción para el mercado interno superó a la correspondiente a exportaciones únicamente en 1956-1960, cuando coincidió con una tasa de crecimiento del sector agropecuario en general bastante inferior a la del producto interno total. Parece evidente que las condiciones de la demanda externa fueron decisivas en el comportamiento de la producción agrícola; esta última aumentó cuando las condiciones eran favorables y se retrajo frente a la caída de precios que se presentó a partir de 1956, aunque esto no parece suficiente para explicar las distintas tasas de crecimiento del sector. Conviene, pues, examinar algunas de las variables que influyeron en el comportamiento del sector agropecuario.

Se señaló antes que la inversión pública cambió de orientación y que en términos absolutos y relativos se fueron asignando menos recursos a las obras de fomento agropecuario, lo que influyó en la tasa de incremento de las superficies beneficiadas con riego.

En 1946-1950, se hicieron obras de riego que beneficiaron 563 miles de hectáreas. El descenso en los gastos de inversión diez años más tarde hizo disminuir esa cifra a 407 miles de hectáreas en 1956-1960. Los menores incrementos de las superficies beneficiadas con riego pueden también haber incidido en la tasa de crecimiento del sector agropecuario, al mismo tiempo que, ante un aumento absoluto cada vez mayor de la población, puede haberse limitado el excedente de productos agrícolas destinados a la exportación. Esto, unido al debilitamiento del mercado internacional de materias primas y a condiciones climáticas poco favorables, puede explicar el débil aumento de la producción agrícola en los últimos años.

Obsérvese que la época de fuerte expansión de la producción agrícola coincide con los años de rápidos incrementos en la superficie beneficiada con riego y, ambos, con la expansión en la producción agrícola para exportación. De hecho, el crecimiento del área regada permite lograr aumentos considerables en. la productividad que facilitan el cremiento de la producción en condiciones más favorables. El aumento del ingreso y de la población, así como el deterioro de los precios relativos (internos y externos), obstaculizaron el incremento de la producción agrícola de exportación. Es más, a partir de mediados de los años cincuenta la tasa de aumento de la producción para consumo interno superó a la de los productos de exportación. Mientras los sectores industrial y comercial mantuvieron en el periodo 1956-1960 su anterior tasa de crecimiento, el sector agrícola no lo hizo, de lo que puede deducirse que el excedente potencial de exportación se redujo al destinarse un mayor porcentaje del producto agrícola al mercado interno. Este rezago del sector agrícola agravó el impacto del deterioro de la relación de intercambio en lo referente a la capacidad para importar. El incremento de la producción de alimentos en parte se debe al abandono de cultivos de exportación, pero si la superficie regada hubiera continuado aumentando a la tasa observada hasta mediados de la década de los cincuenta, el volumen exportado de productos agricolas habria podido ser mayor y ayudado a contrarrestar la influencia del deterioro de la relación de intercambio. Probablemente habría aumentado también el mercado para los productos y servicios de los otros dos sectores, o los movimientos de precios relativos les 
hubieran sido aún más favorables. Pero según se observa en el cuadro 13, la inversión pública a últimas fechas se inclina más hacia los servicios, a la vez que los gastos corrientes del gobierno aumentan rápidamente. Ambos fenómenos actúan en detrimento de la inversión en el sector agropecuario.

\section{LA DISTRIBUCIÓN DEL PRODUCTO NACIONAL}

Según se vio antes, de 1940 a 1962 la producción agropecuaria descendió del 23.2 al $17.2 \%$ del producto bruto interno. La producción industrial ascendió del 31 al $33.9 \%$, y los servicios del 45.8 al $48.9 \%$. El producto por persona ocupada en los servicios era en 1960 de 26772 pesos; en la industria, de 22848 pesos, y en las actividades agropecuarias, de 4259 pesos. Es muy difícil, si acaso es posible, señalar con precisión en qué sentido se ha modificado la distribución del producto nacional. Esto se debe a la inexistencia de estimaciónes de cuentas nacionales. Sin embargo, con base en una encuesta reciente, se pueden hacer algunas consideraciones respecto a la distribución actual del ingreso en los tres sectores que se consideran en este trabajo.14

Las actividades agropecuarias han perdido importancia relativa, pero esto oculta el carácter dual del sector. Si bien la agricultura de subsistencia y los asalariados agrícolas han visto empeorar drásticamente su posición relativa, esto no es así en la agricultura comercializada que, al igual que la industria y los servicios, acusa crecientes ingresos por persona ocupada.

Puede decirse que el crecimiento económico de México tiene carácter urbano. El ingreso medio por persona asciende según el taman̄o de la localidad, y esto es válido para el origen de los ingresos: sueldos y salarios, ingresos mixtos, rendimiento del capital e inversiones, otros

\section{Cuadro 17}

MéXICo: INGReso MENSUAL MEDIO POR PERSONA SEgứn taMaÑo DE LA LOCALIDAD, 1963

(Cifras en pesos)

\begin{tabular}{lcccrrr}
\hline $\begin{array}{c}\text { Tamaño de la } \\
\text { población }\end{array}$ & $\begin{array}{c}\text { Ingreso } \\
\text { total }\end{array}$ & $\begin{array}{c}\text { Sueldos } \\
\text { y } \\
\text { salarios }\end{array}$ & $\begin{array}{c}\text { Empre- } \\
\text { sarios } \\
\text { agri- } \\
\text { colas }\end{array}$ & $\begin{array}{c}\text { Empre- } \\
\text { sarios } \\
\text { noagri- } \\
\text { colas }\end{array}$ & $\begin{array}{c}\text { Capital } \\
\text { einver- } \\
\text { siones }\end{array}$ & $\begin{array}{c}\text { otros } \\
\text { ingresos }\end{array}$ \\
\hline Hasta 2500 habitantes & 125.5 & 61.3 & 46.3 & 8.4 & 9.1 & 0.4 \\
De 2501 a 10000 & 128.8 & 91.5 & 38.6 & 31.9 & 13.2 & 7.6 \\
De 10001 a 150000 & 252.1 & 172.9 & 25.3 & 32.7 & 17.5 & 3.6 \\
De 150000 a 500 000 & 328.4 & 270.7 & 1.1 & 25.5 & 24.7 & 6.4 \\
De 500 001 o más & 484.3 & 276.3 & 4.8 & 132.8 & 59.8 & 10.5 \\
Distrito Federal & 454.8 & 339.3 & 0.04 & 64.1 & 41.4 & 10.0 \\
Promedio nacional & 221.8 & 139.0 & 31.9 & 29.0 & 17.9 & 3.9 \\
\hline
\end{tabular}

Fuente: Citada en el cuadro 10. 


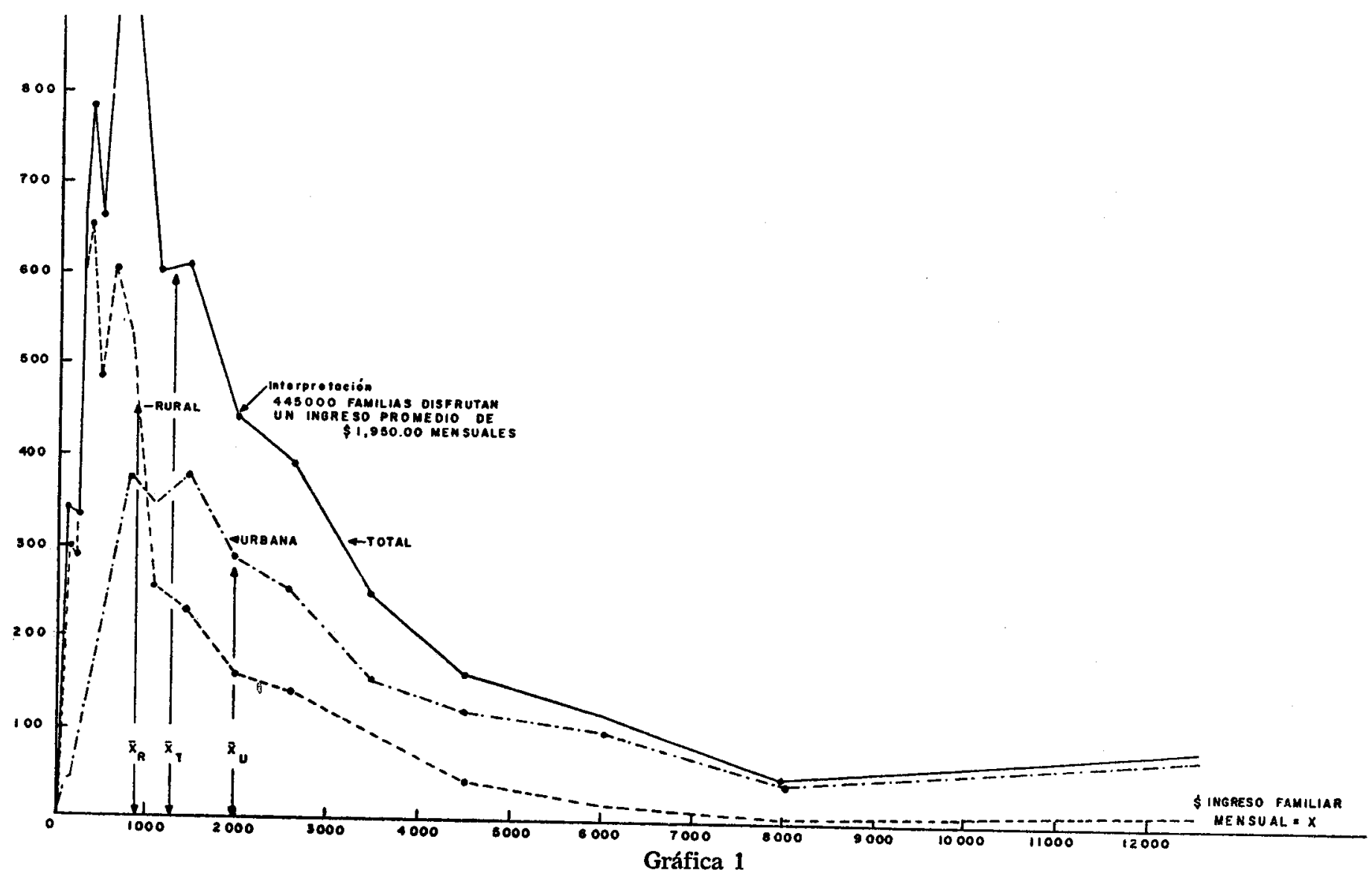

México: Distribución DeL. INGReso famillar MENSUAL, POBlación-Urbana Y RURAL, 1963 Curva natural de distribución 


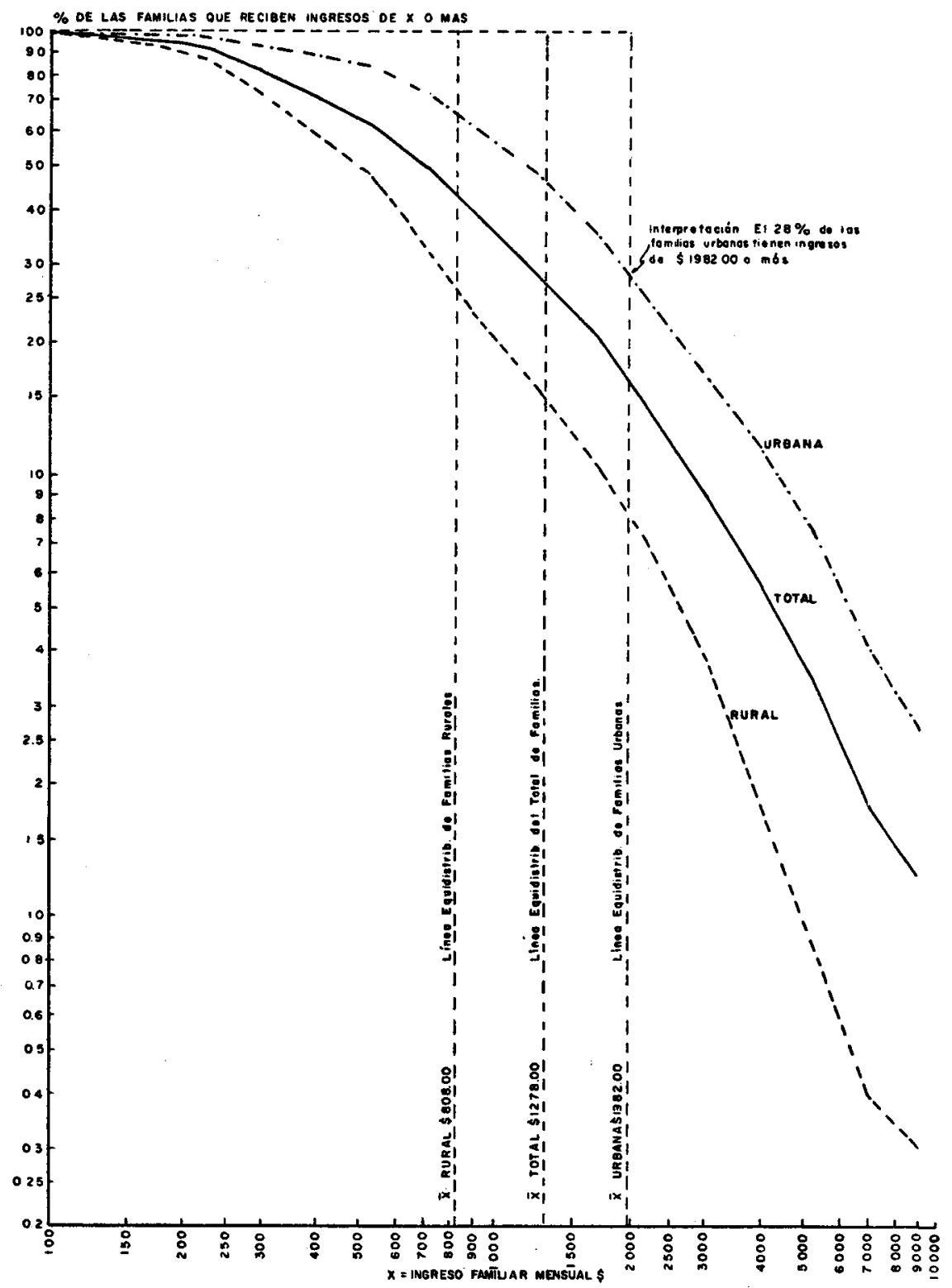

Gráfica 2

Mexico: Distribución del ingreso familiar, población Urbana y RURal, 1963 Curvas de Pareto 


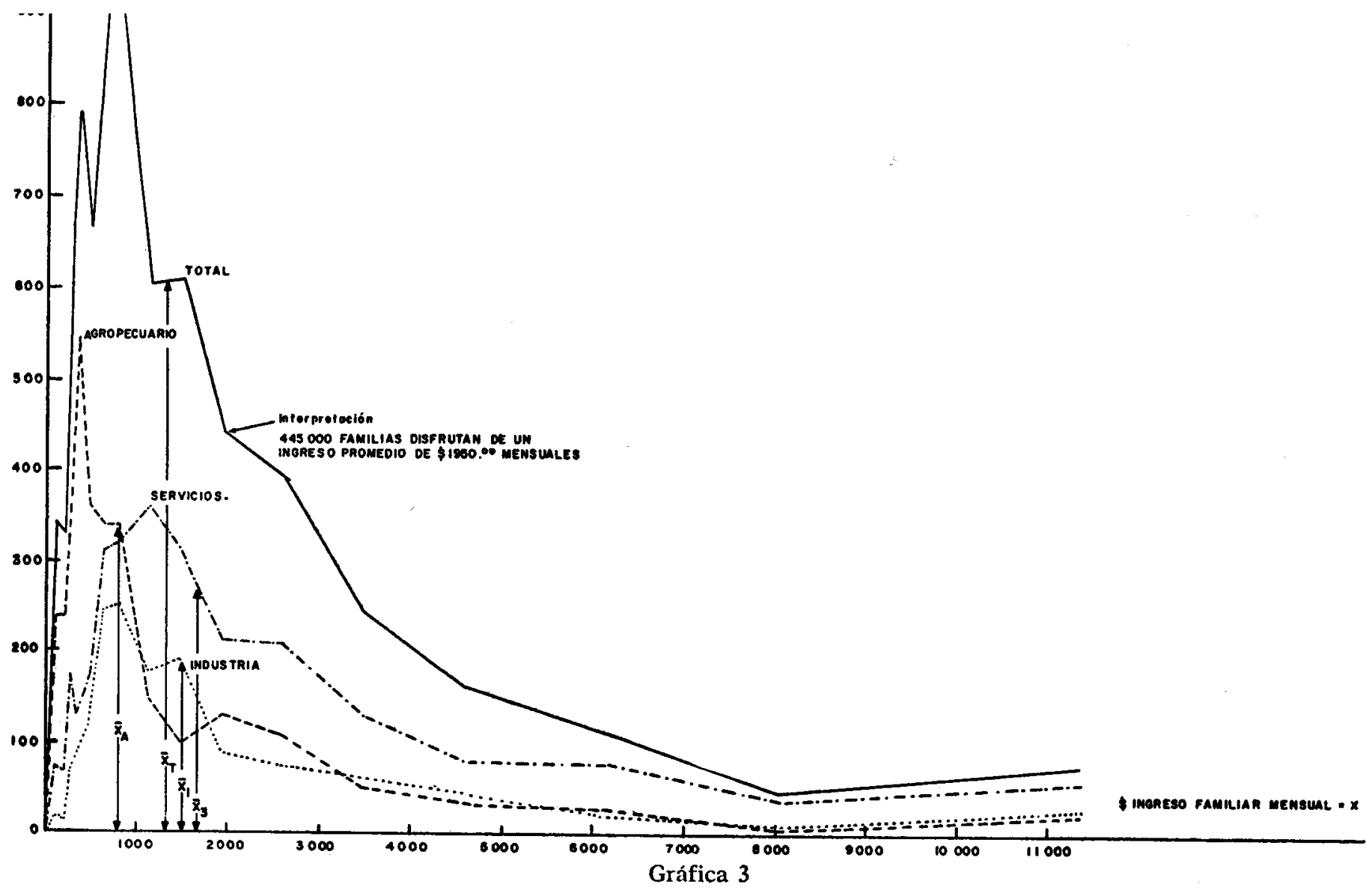

MÉxico: Distribución del INGReso faMiliar Mensual; POR SECTORES DE aCTividad. Curva natural de distribución 
ingresos; y únicamente no lo es para los ingresos provenientes de empresas agricolas que muestran la relación inversa. En general, el ingreso medio por persona en ciudades mayores de medio millón de habitantes es casi cuatro veces superior al de localidades menores de 2500 habitantes.

El nivel del ingreso no sólo es mayor en poblaciones urbanas sino que, además, la distribución del ingreso por frecuencia se aproxima a una curva normal, lo que indica que el grado de desigualdad es menor en las ciudades que en el campo, y menor también en la industria y los servicios que en actividades agropecuarias (Véanse las gráficas 1 a 4.) El coeficiente de Gini es de 2.71 en las zonas urbanas

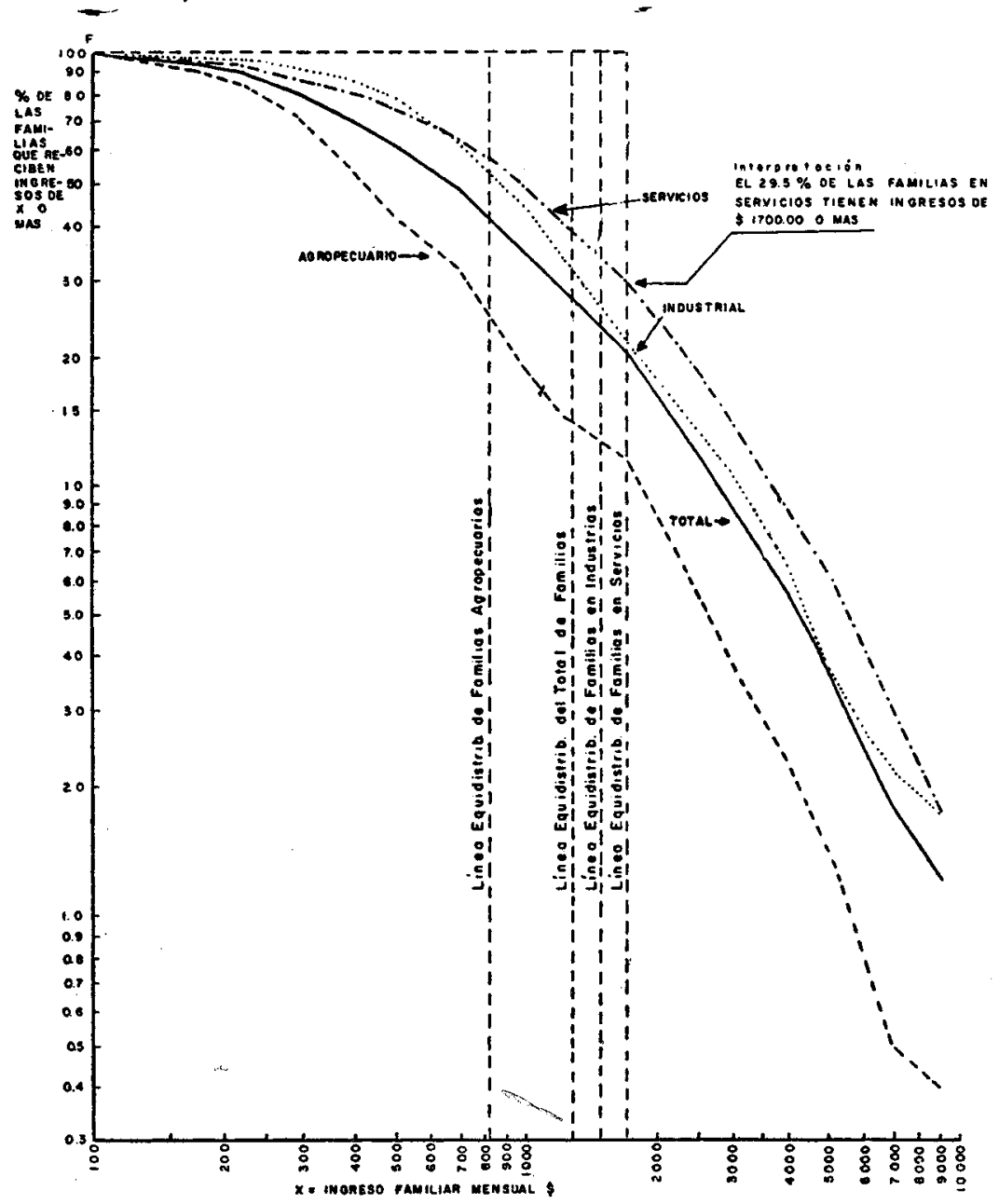

Gráfica 4

MÉxICo: Distribución DEL INGReSo FAMILIAR, POR SECTORES DE ACTIVIDAD 


\section{Cuadro 18}

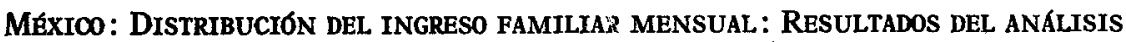
DE DISTRIBUCIÓN, 1963

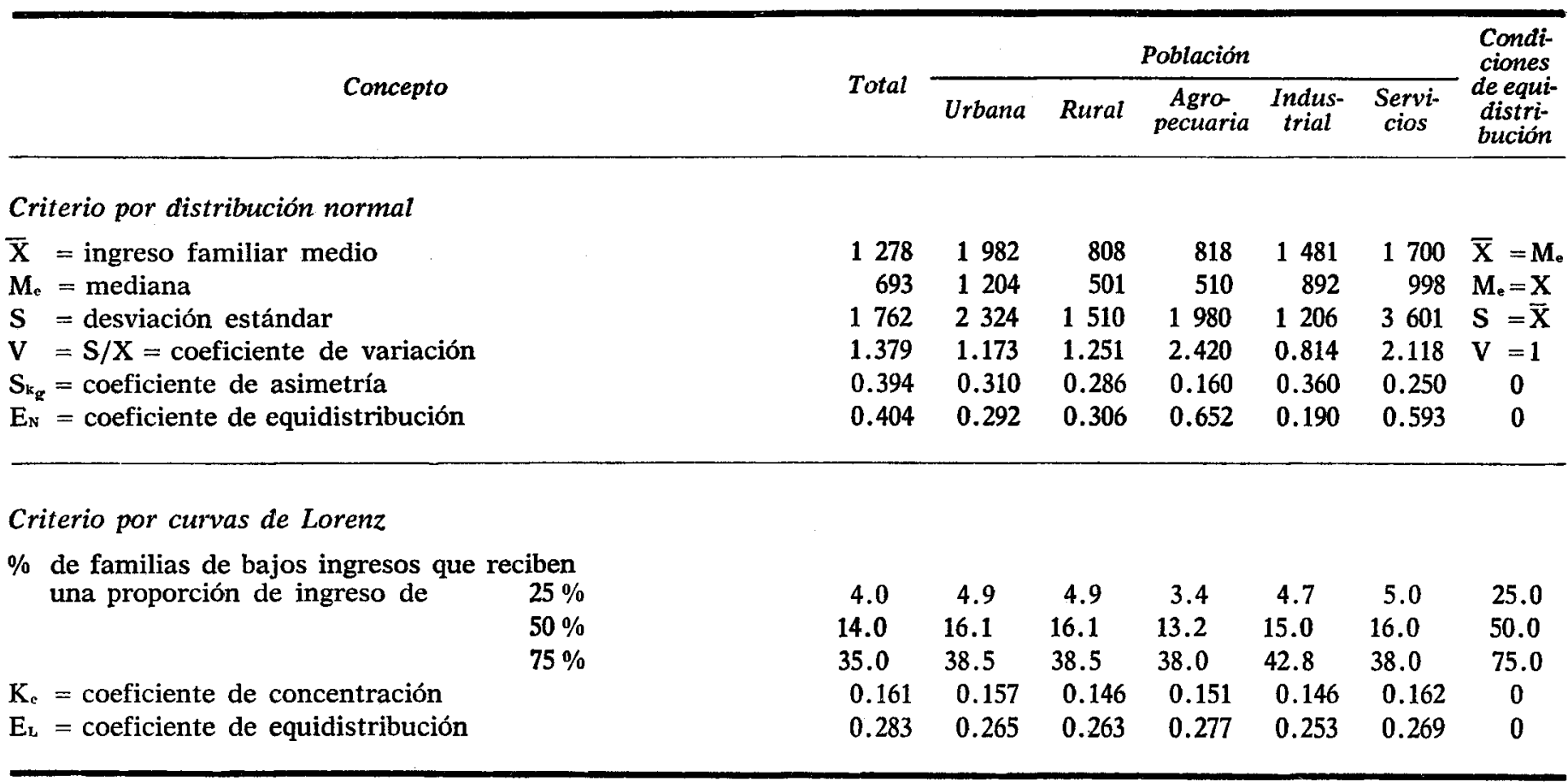




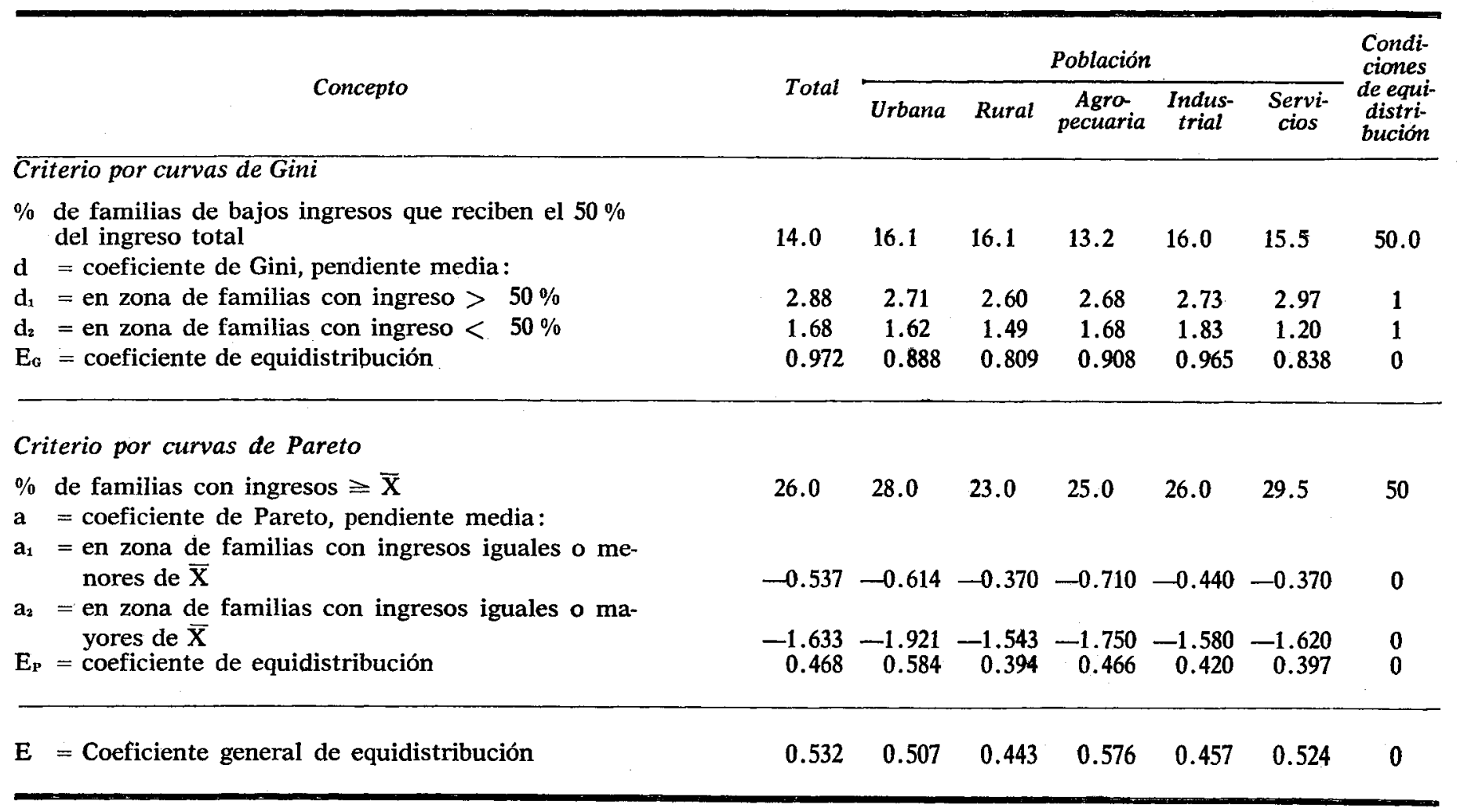

Fuente: Con base en datos de la encuesta citada en el cuadro 10. 
y de 2.60 en las zonas rurales para las familias con ingresos superiores al $50 \%$ del total y de 1.62 y 1.49 para los ingresos menores del $50 \%$ del total. (El coeficiente indica mayor igualdad conforme se aproxima a 1.) (Véase el cuadro 18.) No deja de resultar un tanto extraño este hecho, ya que podría esperarse que la distribución del ingreso agríco. la, como resultado de la reforma agraria, fuese más equitativa que la del ingreso en la industria o en los servicios, inclusive al considerar la influencia de la estructura fiscal por su carácter regresivo. Cabe agregar que en otros países subdesarrollados - que no han tenido reforma agraria- el ingreso rural está distribuido más equitativamente que el ingreso urbano.

Se puede aventurar que la movilidad de los factores que desencadenó la reforma agraria tuvo efectos de dinámica tecnológica no generalizados y que, apoyada por las inversiones públicas de fomento agropecuario, acentuaron el carácter dual del sector agropecuario y en él ahondaron la desigualdad de la distribución que sólo parcialmente había corregido la distribución de tierras. Sin embargo, el análisis por curvas de Pareto indica que la desigualdad en la agricultura es mayor que en la industria y en ésta menos que en los servicios. (La curva de la agricultura es menos cóncava que la de los otros sectores.)

Los porcentajes de población e ingresos, por estratos, en los tres sectores que se distinguen en este estudio, se indican en el cuadro 19.

El nivel medio del ingreso en la agricultura es notoriamente inferior al correspondiente a los otros sectores y la distribución de las personas se aglomera en los estratos bajos de ingreso. El $54 \%$ de

Cuadro 19

MÉxico: Distribución DEL INGReso MENSUAL faMiLIAR POR ESTRATOS Y SECTORES DE ACTIVIDAD

(Porcientos)

\begin{tabular}{|c|c|c|c|c|c|c|}
\hline \multirow{2}{*}{$\begin{array}{c}\text { Estratos de } \\
\text { ingreso } \\
\text { (pesos) }\end{array}$} & \multicolumn{2}{|c|}{ Agropecuario } & \multicolumn{2}{|c|}{ Industrial } & \multicolumn{2}{|c|}{ Servicios } \\
\hline & $\begin{array}{l}\% \text { de las } \\
\text { personas }\end{array}$ & $\begin{array}{l}\% \text { de los } \\
\text { ingresos }\end{array}$ & $\begin{array}{l}\% \text { de las } \\
\text { personas }\end{array}$ & $\begin{array}{l}\% \text { de los } \\
\text { ingresos }\end{array}$ & $\begin{array}{l}\% \text { de las } \\
\text { personas }\end{array}$ & $\begin{array}{l}\% \text { de los } \\
\text { ingresos }\end{array}$ \\
\hline 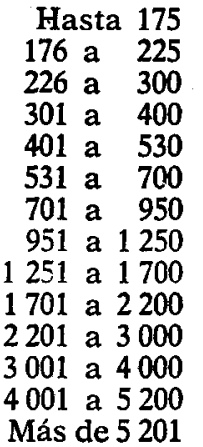 & $\begin{array}{r}6.9 \\
7.1 \\
12.4 \\
16.1 \\
12.1 \\
12.1 \\
10.1 \\
5.0 \\
3.7 \\
5.2 \\
3.6 \\
2.3 \\
1.2 \\
1.5\end{array}$ & $\begin{array}{r}1.3 \\
2.1 \\
4.7 \\
7.8 \\
7.2 \\
9.0 \\
12.0 \\
6.1 \\
6.1 \\
8.0 \\
11.3 \\
7.7 \\
5.3 \\
10.0\end{array}$ & $\begin{array}{r}1.0 \\
0.9 \\
3.2 \\
5.8 \\
7.1 \\
15.6 \\
16.0 \\
11.9 \\
12.7 \\
6.8 \\
5.9 \\
5.3 \\
3.7 \\
4.1\end{array}$ & $\begin{array}{r}0.3 \\
0.6 \\
3.4 \\
3.8 \\
5.0 \\
15.5 \\
13.0 \\
12.0 \\
15.0 \\
11.2 \\
4.0 \\
11.5 \\
2.2 \\
2.0\end{array}$ & $\begin{array}{r}1.9 \\
1.4 \\
5.9 \\
4.2 \\
6.4 \\
11.1 \\
12.7 \\
9.9 \\
13.3 \\
8.2 \\
8.5 \\
6.0 \\
3.3 \\
6.9\end{array}$ & $\begin{array}{r}0.7 \\
1.2 \\
4.0 \\
4.6 \\
4.4 \\
11.5 \\
12.4 \\
9.5 \\
15.0 \\
8.2 \\
10.9 \\
10.0 \\
5.2 \\
2.4\end{array}$ \\
\hline
\end{tabular}

Fuente: Citada en el cuadro 10. 
las personas ocupadas en el sector agropecuario, según la encuesta señalada, recibe el $23 \%$ del ingreso, con percepciones menores de 530 pesos de ingreso familiar mensual; en la industria, la mitad de las personas ocupadas recibe el $42 \%$ del ingreso, con percepciones mensuales de ingreso familiar menores de 950 pesos; en los servicios, el $54 \%$ de las personas recibe el $48 \%$ de los ingresos, con percepciones menores de 1250 pesos mensuales de ingreso familiar.

Es claro, entonces, que la movilidad de la mano de obra del campo a la ciudad, y su desplazamiento de la agricultura a la industria y los servicios, tiende a elevar el ingreso por persona y a hacer más equitativa la distribución del ingreso nacional. Cabe recordar que este proceso ha operado como un factor correctivo por bastante tiempo. Sólo en el decenio de 1950 a 1960 el crecimiento de la población urbana fue de $4.9 \%$ anual y la rural de $1.5 \%$ anual.

\section{UNA SÍNTESIS DEL CRECIMIENTO}

No se dispone de una explicación totalmente satisfactoria del desarrollo económico de México. La falta de investigación económica sistemática de las variables más importantes ha orillado, en algunos casos, a explicarse el desarrollo de México como consecuencia de una serie de acontecimientos fortuitos y de actos políticos francamente pragmáticos cuya exclusiva finalidad era resolver los problemas del momento. Sobre el futuro económico de México, Raymond Vernon presagió recientemente una parálisis económica debida a la imposibilidad para actuar en vista de que se ha establecido un equilibrio de fuerzas: el deseo de no perjudicar ni poderosos intereses creados ni influyentes grupos políticos conducirá a la inacción.13 Según él, ante la imposibilidad de predecir un nuevo hecho fortuito, un Deus ex machina que exorcize el letargo que inexorablemente se aproxima, surge el dilema en forma de disyuntiva inescapable: modificación política o estancamiento económico. Es interesante observar que la predicción económica de Vernon se basa fundamentalmente en un hecho político y esto, me parece, refleja en parte lo poco que se conoce acerca del crecimiento económico del país. En realidad, su libro no es sino uno más de una serie de estudios que, contradiciendo hipótesis anteriores, terminan dando la voz de alarma sobre este o aquel problema que impide la continuación del desarrollo económico del país. Pese a todo, el desarrollo sigue una tasa de crecimiento secular de $6 \%$ anual. Este hecho muestra la complejidad del problema y lo peligroso de especular sobre el tema; sin embargo, este trabajo quedaría inconcluso sin un intento de explicación de los fenómenos apuntados que además pueda servir para indicar la importancia de ciertos temas concretos de investigación. A continuación trataré de presentar una hipótesis con la que pretendo llegar a una deducción congruente con el comportamiento de las variables analizadas a lo largo de este estudio.

Durante el último cuarto de siglo la economía mexicana se ha des-

15 Raymond Vernon, The Dilemma of Mexico's Development: the roles of the private and the public sectors, Cambridge. Harvard University Press, 1963. (Version en español: El dilema del desarrollo económico de México; papeles representados por los sectores público y privado, México, Editorial Diana, 1966.) 
arrollado a una tasa de 2.5 a $3.0 \%$ por habitante. E1 crecimiento sectorial de la industria y los servicios ha sido más rápido que el de las actividades agropecuarias. En general, ha sido un proceso hacia formas más capitalizadas de producción: industria, servicios, agricultura comercializada de riego. Este cambio sectorial concuerda con la estructura de la demanda, que presenta bajas elasticidades del consumo de alimentos y mayores elasticidades para los bienes manufacturados -especialmente los de consumo duradero. Es decir, a aumentos del ingreso corresponde mayor consumo de bienes industriales y menor de productos agrícolas. El desarrollo global es compatible con tasas más rápidas de crecimiento de la industria y los servicios, y más lenta del sector agropecuario.

En general, el cambio estructural sigue las indicaciones de la demanda interna. El incremento del producto del sector agropecuario, de $4.9 \%$ en 1941-1956 y de $4.2 \%$ en 1956-1964, fue compatible con el comportamiento de la demanda, e inclusive, durante el primer período, permitió excedentes exportables crecientes y sustitución de importaciones. Recuérdese que los precios relativos internos se movieron en contra del sector agropecuario, así que las cotizaciones de productos agrícolas contuvieron el alza del índice general. Conviene hacer hincapié en que el dinamismo del sector agropecuario, aun frente a precios cuyos movimientos le eran adversos, hizo posibles cambios de la productividad que permitieron alimentar una población creciente y ocupar una proporción decreciente de la misma. La transferencia de población del campo a la ciudad significa una inversión del sector agropecuario en capital humano que aprovechan los sectores situados en zonas urbanas.

El sector agropecuario ha mostrado amplia capacidad para asimilar cambios técnicos que se manifiesta en el aumento del producto por persona y de los rendimientos por hectárea, sobre todo en la agricultura comercializada. A diferencia de lo que ocurría en el Porfiriato y sucede en otros países latinoamericanos, el sector agropecuario (el sector económico de menor tasa de crecimiento) se desarrolla con la suficiente rapidez para satisfacer las necesidades internas, frenar el alza de precios y producir un excedente cada vez mayor para exportación. Los aumentos de productividad se deben a cambios cuantitativos y cualitativos de los insumos y de su costo (innovaciones), al avance cultural de la población y a adelantos tecnológicos que el sector agropecuario ha sabido aprovechar. Las inversiones en regadio, transportes, investigación y extensión agrícola no fueron pagadas directamente por el sector agropecuario, así que constituyeron insumos productivos obtenidos sin desembolso o a precio inferior al costo de producción. El programa educativo puso a disposición de la población rural innumerables posibilidades de acción económica, social y cultural.

El avance tecnológico y las innovaciones productivas fueron importantes en la industria y los servicios, actividades donde el avance cultural es mayor y la base de desarrollo más amplia. El fácil acceso a fuentes abundantes de energía, de mano de obra en expansión - y por tanto de bajo costo-, los subsidios al consumo, el acceso al financiamiento y el apoyo gubernamental explican de sobra la superioridad de las actividades urbano-industriales respecto a la agricultura. 
Algunas investigaciones de la economía norteamericana indican que el adelanto tecnológico es la causa más importante de crecimiento del ingreso. En México, el contenido de importaciones de la inversión, el avance educativo logrado, el aumento de las inversiones extranjeras - con su desplazamiento de tecnología-, son factores que corroboran la gran importancia del avance tecnológico como explicación del crecimiento; el uso de la tecnología avanzada genera considerables economías externas, principalmente producidas por el gasto público, que son captadas internamente por el sector privado en forma de mayores beneficios. Las economías externas han resultado, entre otras, de mejoras en las comunicaciones, ampliación de las zonas de riego, mejoras en la calificación de la mano de obra, y fortalecimiento y expansión de la base industrial.

Aunque antes se señaló que el mecanismo de transferencia intersectorial no operó abiertamente en detrimento del sector agrícola, no se puede pretender que no haya influido en su comportamiento. El mecanismo fiscal captó recursos del sector agropecuario principalmente mediante impuestos a la exportación de productos agropecuarios y a la importación de bienes adquiridos por este sector. Esos fondos los reintegró al sector agrícola en forma de inversión pública en obras de fomento agropecuario, especialmente en riego, aun cuando en el último cuarto de siglo el mecanismo fiscal no intentó deliberadamente captar el excedente agrícola para transferirlo al desarrollo de los sectores urbanos, como ha sido el caso de muchos países. Sin embargo, el sector urbano-industrial extrajo ahorros del sector agrícola pero al mismo tiempo forzó la capitalización del sector agropecuario, ya que los impuestos se reinvirtieron en la agricultura, forma de crear un excedente que fue invertido en el propio sector. Esto significa, en parte, que funcionó un proceso de canalización de recursos de la agricultura de subsistencia y de exportación (por ejemplo, del café), a la agricultura comercializada. Así puede explicarse en parte la desigual distribución del producto agropecuario.

Después de la reforma agraria, el antagonismo entre el campesinado y la población urbana desapareció. Mientras que durante el Porfiriato hubo disputas respecto a la política arancelaria, y los latifundistas resistieron la política de protección industrial que encarecía las manufacturas importadas, en la época más reciente el conflicto no tuvo lugar abiertamente. La reforma agraria, al liquidar el poder político de los terratenientes, facilitó la aplicación de una política proteccionista agresiva: la falta de integración política de los grupos afectados, la fluidez traída por las nuevas circunstancias y la dífícil oposición a una política económica que satisficiera las aspiraciones de tierras de los campesinos, evitaron la resistencia rural a la política de protección al desarrollo industrial. Ésta se llevó a cabo casi sin competencia externa y ayudada por cambios de precios relativos que favorecían su crecimiento.

En síntesis, una constelación favorable de potentes fuerzas facilitó el desarrollo industrial. Este se debió en parte a la expansión sostenida del sector externo, principalmente por crecimiento de exportaciones agrícolas y por la posibilidad poco común de exportar servicios -turismo y braceros-, al creciente nivel del gasto público y al aumen- 
to de la población y de la reserva rural urbana de fuerza de trabajo. Además, los precios relativos favorables, los estímulos físcales, la inversión en obras de fomento industrial -energía, que se vendía a precios que aumentaban menos que el nivel general de precios-y los subsidios al consumo de la fuerza de trabajo urbana fueron factores que apoyaron el desarrollo industrial. Todos estos sucesos fomentaron la expansión del mercado interno. Además, la ampliación del sector público le dio mayor importancia a la inversión autónoma -la cual no depende de las oscilaciones a corto plazo-; aminoró la influencia de la inversión inducida y estabilizó el crecimiento del producto.

Las fuerzas que influyeron en el desarrollo industrial actuaron para abatir el costo de los insumos. La educación de la fuerza de trabajo, la reserva de mano de obra y su alta movilidad, el crecimiento de la población y los subsidios al consumo urbano (alimentos básicos, transportes, combustibles, etc.) permitieron abaratar el costo de la mano de obra por unidad de producto. El avance tecnológico fue también un elemento favorable. Por una parte, los bienes de capital importados ganaron en productividad - debido al avance tecnológico de los países industrializados - aumentando su capacidad productiva por unidad de costo y economizando materias primas; por otra, la mayor calificación de técnicos y profesionales, y en general de los cuadros directivos, produjo innovacionès en la organización y mejoras de eficiencia que elevaron la redituabilidad de las empresas o las hicieron menos riesgosas.

Todo esto, sin duda, propició el aumento de las utilidades, del ingreso de la propiedad y del ahorro privado. Fue estimulada la inversión y facilitado su financiamiento a la vez que se hicieron menos agudas las limitaciones impuestas por la estrechez del mercado financiero y la poca importancia de las instituciones crediticias en el financiamiento de la inversión. El bajo nivel de la carga impositiva, si bien en ocasiones creó fuertes presiones sobre la expansión crediticia y la estabilidad monetaria, evitó que la política fiscal actuara en detrimento del ahorro de los individuos y de las empresas y dificultara la reinversión de utilidades.

La distribución del ingreso, la importancia del autofinanciamiento, la iniciación de actividades productivas nuevas y la importación de capital privado y de tecnología dieron lugar a estructuras de mercado oligopólicas y monopólicas con precios y utilidades del mismo tipo. Sin duda, la formación de unos cuantos grupos financieros y sus ramificaciones en actividades productivas coadyuvaron a la concentración de la propiedad de las empresas y facilitaron la acumulación de la riqueza en pocas manos. Es difícil opinar sobre el significado de este proceso de concentración, en términos de eficiencia económica; pero el conocimiento del mecanismo del desarrollo de México es fundamental para planear la futura prosperidad económica del país y para comprender las raíces de su estabilidad política.

En el período más reciente del desarrollo del país se aprecia la transición de una etapa de desarrollo con inflación, que termina en 1956 aproximadamente, a una etapa de crecimiento con estabilidad de precios. Todo indica que durante la época de inflación se realizaron los cambios institucionales $\mathrm{y} /$ forjaron los instrumentos de política 
económica que hicieron posible la etapa más reciente de desarrollo con estabilidad. Los cambios institucionales consistieron básicamente en la mayor movilidad de la tierra, del capital y de la mano de obra; la elevación del nivel educativo y, por consiguiente, el aumento de la capacidad de absorción de adelantos tecnológicos y la formación de una clase empresarial ; la mayor importancia de las decisiones de inversión tomadas por residentes; la menor dependencia del exterior, y la monetización y mayor vinculación de la economía entre sus distintos elementos. Estos instrumentos permitieron mejorar la asignación de factores productivos, facilitando a la industria y a la agricultura el acceso al crédito institucional y al crédito externo para fines de desarrollo; hicieron posible crear un mecanismo de colocación de deuda y de captación de ahorro interno y externo y, finalmente, proporcionaron los estímulos fiscales y de política comercial necesarios para la sustitución de importaciones que, a su vez, favoreció el crecimiento industrial. En el momento en que se dio este concierto de elementos y mecanismos de canalización de ahorros a inversión productiva, de equilibrio sectorial y absorción de cambios tecnológicos, la política de estabilización pudo tener éxito. Así, la contracción monetaria ejercida después de la devaluación de 1954, elevó la tasa real de interés; sin embargo, la inversión pública, financiada con crédito externo, junto con la considerable inversión autónoma y la continuación del proceso de sustitución de importaciones, mantuvo el ritmo de capitalización y gasto hasta que el incremento del ingreso así generado vitalizó e indujo aumentos de la inversión privada y anuló el efecto desestimulante de la contracción crediticia y del aumento del costo del dinero.

Puede preguntarse, sin embargo, si, en términos del costo de oportunidad, conviene asignar más recursos - relativamente- al sector agropecuario para acelerar su tasa de crecimiento, apresurar el aumento de la productividad agrícola y elevar al máximo el producto marginal social. Los efectos indirectos de esta política podrían ser notables: precios relativos favorables al sector urbano, que en caso de ser menores al cambio de la productividad no afectarían desfavorablemente el ingreso agrícola; aceleración del desarrollo industrial por aumento de la demanda de insumos y de bienes de uso final por el sector rural; incremento de la capacidad para importar y eliminación gradual de la agricultura de subsistencia. Como el crecimiento urbano facilita el desarrollo industrial y de los servicios, en función de la estructura de la demanda urbana, y de la exportación de servicios, conviene transferir a las ciudades mano de obra barata proveniente del sector agropecuario. En México se observa una asociación directa entre el nivel de ingreso per capita y el grado de urbanización. Cada persona que pasa del campo a la ciudad aumenta su probabilidad de tener un empleo mejor remunerado. Como complemento, es válido preguntarse si el sector industrial y el de servicios pueden convertirse en generadores aún más importantes de divisas, tanto por la continuación del proceso de sustitución de importaciones como también mediante la exportación de servicios y bienes manufacturados.

Se dice con frecuencia que la sustitución de importaciones se hace más difícil una vez que se generan internamente bienes de consumo manufacturados que produce la industria ligera. Pero después, se agre- 
ga, el tamaño del mercado se convierte en un obstáculo a la continuación del proceso de sustitución de importaciones, el que, en caso de realizarse, se logra a costos crecientes desaprovechando las ventajas de la especialización internacional. Esto es difícil de admitir. No parece existir, a priori, razón que fundamente la peculiar indivisibilidad del equipo en la producción de maquinaria. La historia económica y la fabricación actual de equipo pesado en países industrializados sugieren lo opuesto en muchas ramas. Se puede afirmar, por el contrario, que la fabricación de maquinaria y equipo es tamúién divisible, pero que requiere del uso abundante de un factor escaso en los países poco desarrollados: conocimientos tecnológicos. Esto parece indicar que la inversión en capital humano en. la forma de gastos en educación, sobre todo media y superior, que ha venido creciendo como parte del producto nacional y del gasto gubernamental y privado, será un factor que permita proseguir la sustitución de importaciones, incrementar la capacidad para importar y eliminar uno de los obstáculos más graves a que continúe el proceso de desarrollo económico del país. 